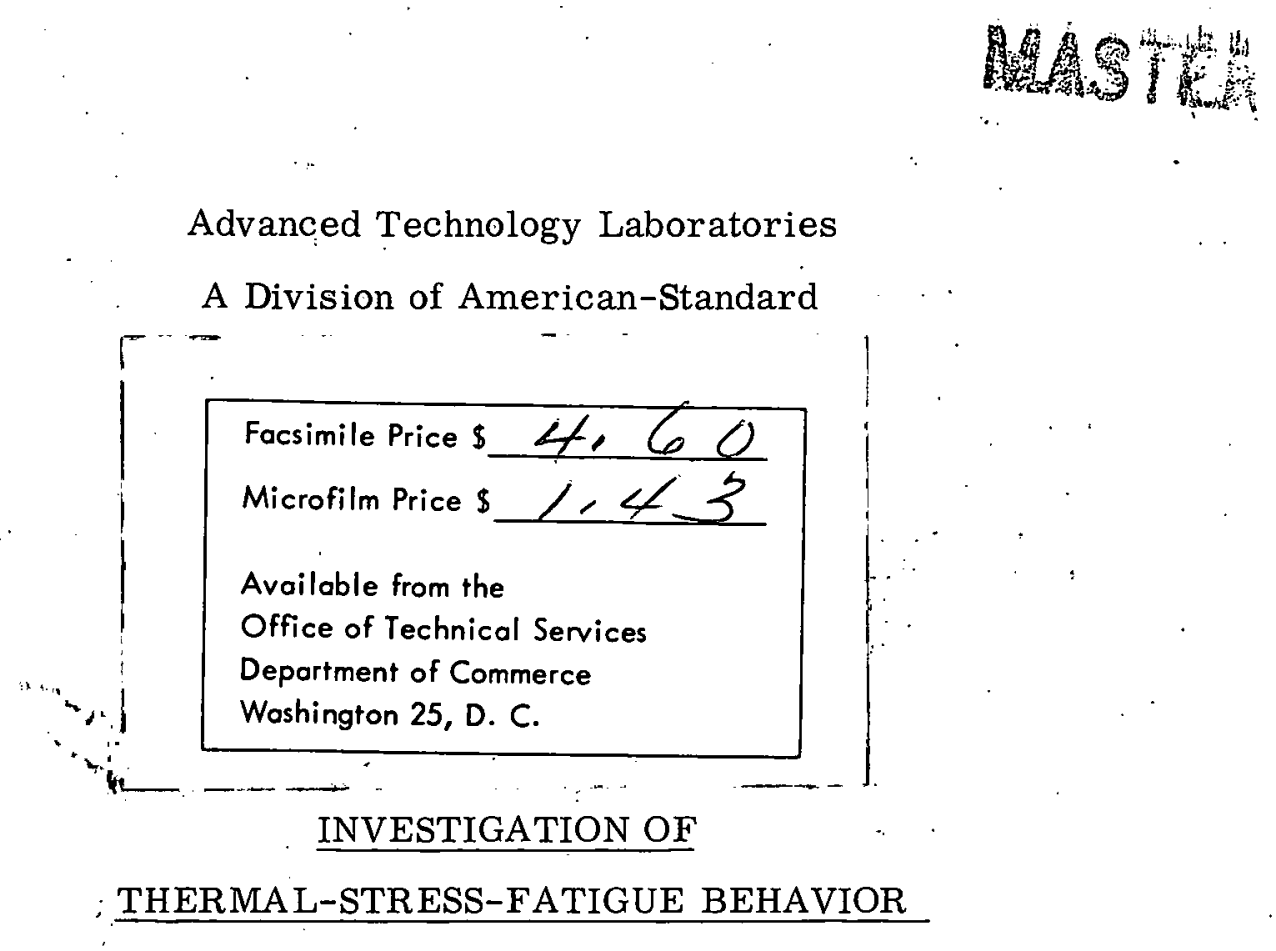

\title{
OF STAINLESS STEELS
}

Prepared under

AEC Contract AT(04-3)-250

Project Agreement No. 11

for the

Joint U. S. -Euratom Research and Development Board

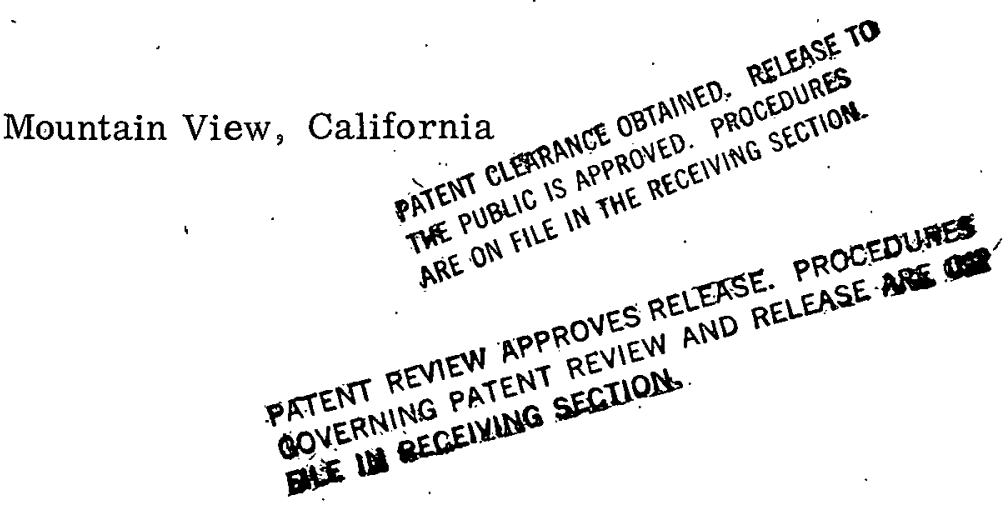




\section{DISCLAIMER}

This report was prepared as an account of work sponsored by an agency of the United States Government. Neither the United States Government nor any agency Thereof, nor any of their employees, makes any warranty, express or implied, or assumes any legal liability or responsibility for the accuracy, completeness, or usefulness of any information, apparatus, product, or process disclosed, or represents that its use would not infringe privately owned rights. Reference herein to any specific commercial product, process, or service by trade name, trademark, manufacturer, or otherwise does not necessarily constitute or imply its endorsement, recommendation, or favoring by the United States Government or any agency thereof. The views and opinions of authors expressed herein do not necessarily state or reflect those of the United States Government or any agency thereof. 


\section{DISCLAIMER}

Portions of this document may be illegible in electronic image products. Images are produced from the best available original document. 


\section{LEGAL NOTICE}

This document was prepared under the sponsorhsip of the U.S. Atomic Energy Commission pursuant to the Joint Research and Development Program established by the Agreement for Cooperation signed November 8,1958 , between the Government of the United States of America and the European Atomic Energy Community (Euratom). Neither the United States, the U.S. Atomic Energy Commission, the European Atomic Energy Community, the Euratom Commission, nor any person acting on behalf of either Commission:

a. Makes any warranty or representation, expressed or implied, with respect to the accuracy, completeness, or usefulness of the information contained in this report, or that the use of any information, apparatus, method, or process disclosed in this document may not infringe privately owned rights; or

b. Assumes any liabilitiès with respect to the use of, or for damages resulting from the use of any information, apparatus, method, or process disclosed in this document.

As used in the above, "person acting on behalf of either Commission" includes any employee or contractor of either Commission or employee of such contractor to the extent that such employee or contractor or employee of such contractor prepares, handles, disseminates, or provides access to, any information pursuant to his employment or contract with either Commission or his employment with such contractor. 
EURAEC- 555 ,

ATL-A-134

Joint U.S. -Euratom Research and Development Report

Special Distribution

\section{INVESTIGATION OF}

\section{THERMAL-STRESS-FATIGUE BEHAVIOR}

OF STAINLESS STEELS

Quarterly Progress Report No. 4

ATL Job 121200

October-December 1962

Submitted by:

K. E. Horton

R. S. Stewart
Approved by:

H. R. Hulett

D. D. Foley

Advanced Technology Laboratories

A Division of American-Standard

369 Whisman Road

Mountain View, California

Prepared under

AEC Contract AT (04-3)-250

Project Agreement No. 11

$\because$ for the

Joint U.S. -Euratom Research and Development Board 


\section{INTRODUCTION}

The United States and the European Atomic Energy Community (Euratom), on May 29, and June 18, 1958, signed an agreement which provides a basis for cooperation in programs for the advancement of the peaceful applications of atomic energy. This agreement, in part, provides for the establishment of the Joint U.S. -Euratom research and development program which is aimed at reactors to be constructed in Europe under the Joint Program.

The work described in this report represents the Joint U.S. -Euratom effort which is in keeping with the spirit of cooperation in contributing to the common good by the sharing of scientific and technical information and minimizing the duplication of effort by the limited pool of technical talent available in western Europe and the United States. 


\section{SUMMARY}

The program to date has been concerned with the thermal-stress-fatigue (TSF) and strain-cycling-fatigue (SC) testing of Types 304 and 304-L stainless steels. The test variables included atmospheric surroundings, høld time, specimen size; and mean temperature. Results indicate a significant difference in fatigue life between annealed and cold-worked material. No significant difference in fatigue life results from testing in argon as opposed to air. Metallographic structural analysis has shown the effects of strain softening as well as various modes of plastic deformation.

The program has now reached the state where it will soon be necessary to decide upon the next material for testing. In connection with the remainder of the program, consideration should be given to using a new specimen design that will permit more accurate measurement of plastic strain.

As was stated in the last quarterly progress report, emphasis is still being placed on the metallographic examination of fatigued specimens. 


\section{PRINCIPAL INVESTIGATORS}

Investigators on the project include K. E. Horton, Project Leader, and R. S. Stewart, Section Supervisor.

\section{STATEMENT OF PROBLEM}

The thermal-stress-fatigue behavior of reactor materials, in particular stainless steels, cannot be predicted by extrapolation of known data such as conventional fatigue data. Because thermal fatigue may be a major consideration in reactor core and vessel design, suitable engineering data are needed. The objective of this program is to obtain thermal-stress-fatigue data on various types of stainless steels for the conditions that may be encountered in reactor operation and if possible to separate the effects of the various environmental and metallurgical variables. The isolation of variables should allow a theoretical treatment of data that would eventually lead to the formalization of generalized equations for predicting thermal-stress-fatigue life for any reactor conditions.

\section{PROGRESS OCTOBER-DECEMBER 1962}

\section{A. Test Results (Mechanical)}

\section{Conventional Specimens}

During the quarter; tests were conducted primarily on Type 304-L stainless steel, using the specimen design shown in Figure 1. This design can be considered "conventional" since it has been used by Coffin, ${ }^{1}$ Mehringer and Felgar ${ }^{2}$ at General Electric, Carden and Sodergren ${ }^{3}$ at the University of Alabama, Majors ${ }^{4}$ at the University of Seattle, and Horton and Stewart ${ }^{5}$ at Advanced Technology Laboratories. As mentioned in the last quarterly report, ${ }^{6}$ the measurement of plastic strain in this design is somewhat uncertain. Further discussion on this matter is presented in a later section of this report in association with the results of a theoretical stress analysis on a new specimen design.

1. Supercripts indicate list of references, page 13. 
The tests conducted during the quarter are listed in Table I. A summary of the results of tests on annealed and cold-worked 304-L stainless steel at three different mean temperatures, showing the plastic strain per cycle $\left(\Delta \epsilon_{p}\right)$ versus cycles to failure $(\mathrm{N})$, is presented in Figure 2. There is definitely a band within which most of the tests lie. The horizontal bandwidth represents the scatter in data for a variety of test conditions. The fact that the band is comparatively narrow supports the choice.of $\Delta \epsilon_{p}$ as the dependent variable.

The decision to use $\log -\log$ graph paper to plot $\Delta \epsilon_{\mathrm{p}}$ versus $\mathrm{N}$ stems from previous knowledge of the empirical relation. found for TSF test results ${ }^{1,5}$ :

$$
\mathrm{N}^{\mathrm{K}} \Delta \epsilon_{\mathrm{p}}=\mathrm{C}
$$

where $\mathrm{K}=$ constant $\cong \frac{1}{2}$, and $\mathrm{C}=$ material constant. Equatjon 1 becomes

$$
\mathrm{K} \ell \mathrm{n} \cdot \mathrm{N}+\ln \Delta \epsilon_{\mathrm{p}}=\mathrm{C}^{\prime},
$$

and the log-log relationship is clearly evident.

The testing of 304-L stainless steel is still in progress. Because the test conditions are chosen to keep the machines operating and to use the available machined specimens, a strictly ordered sequential study of variables is not being performed. Thus, the dataplotted in Figure 2 are not complete in regard to any particular set of test conditions. For instance, the graph shown in Figure 3 is drawn for the purpose of comparing the TSF lives in air of cold-worked and annealed 304-L stainless steel. However, a similar graph for argon cannot be drawn as yet, since the data are still incomplete. The two curves shown in Figure 3 indicate a crossover in the abilities of the specimens to absorb damage (plastic strain). This conclusion is consistent with similar tests performed on zirconium by Horton and Stewart ${ }^{5}$ and on 347 stainless steel by Coffin. 1

The effect of hold time has been partially investigated, and the results are shown in Figure 4. There does not appear to be an "independent" effect other than its influence on the quantity $\Delta \epsilon_{\mathrm{p}}$. This, of course, is in contrast to the effect of cold work as shown in Figure 3. No noticeable effect of hold time in curves of $\Delta \epsilon_{\mathrm{p}}$ versus $\mathrm{N}$ has been obtained by Carden ${ }^{7}$ from his tests of Hastalloy N. On the other hand, Coffin ${ }^{1}$ obtained an effect when $\mathrm{N}$ was plotted versus hold time for 347 stainless steel; however, an effect would be expected in this type of presentation. 
The effect of the surrounding atmosphere on fatigue life is shown in Figure 5. Again, no noticeable effect is detected when data are plotted on $\Delta \epsilon_{\mathrm{p}}$ versus $\mathrm{N}$ coordinates. It should be mentioned that although oxidation was greatly retarded, it was not completely arrested in argon tests. These results indicate that stress corrosion was probably not influencing the behavior. Had stress corrosion been significant, the data points would lie outside the band of normal data on $\ln \Delta \epsilon_{p}$ versus $\ln N$ curves, since $\Delta \epsilon_{p}$. makes no allowance for this type of behavior per se.

From Figures 3, 4, and 5, it may be argued that a fundamental expression should be chosen for the abscissa such that temperature can be treated as an independent variable. Following are examples of such fundamental expressions.
a) The Larson-Miller Parameter ${ }^{8}$ :

$$
K=T(C+\log t),
$$

where $\mathrm{T}=$ temperature,

C. $=$ constant $\cong 20$,

t = stress-rupture time.

b) The Feltner-Morrow Relationship ${ }^{9}$ :

$$
\log \sigma_{a}=K-(n / 1+n) \log N,
$$

where $K=\log [U(1+n) / 2 k] n / n+1$,

$\mathrm{U}=$ area of stress-strain hysteresis loop,

$\mathrm{k}=$ proportionality constant between stress and plastic $\operatorname{strain}=\epsilon_{\mathrm{p}} / \sigma^{1 / \mathrm{n}}$,

$\mathrm{n}=$ slope of plastic strain versus stress on logarithmic coordinates,

$\mathrm{N}=$ cycles to failure,

$\sigma_{a}=$ one-half of total stress change during fatigue life.

c) The Goldfein Parameter ${ }^{10}$ for a Second-Order Reaction:

$$
K=\frac{T_{0}}{T_{\odot}-T}\left(22.78+\log \frac{a t}{2}\right),
$$

where $\mathrm{T}, \mathrm{T}_{\mathrm{o}}=$ temperature,

a $=$ product of concentration of reactant or square of concentration of one reactant (moles per liter),

$\mathrm{t}=$ stress-rupture time. 
The first and last parameters are easily derived starting from the Arrhenius rate equation. Thus,

$$
\text { Rate }=\mathrm{A} \exp (-\mathrm{Q} / \mathrm{RT})
$$

where $\mathrm{A}=$ constant,

$Q=$ activation energy,

$\mathbf{R}=$ gas constant.

Either by substituting $1 / \mathrm{t}$ for rate or by having rate in the form of a reaction velocity constant; equations 2 and 4 are developed. Such a development has not been previously applied to thermal-stress fatigue. It is a simple matter to do so, however, by assuming that rate is inversely proportional to $\Delta \epsilon_{p} N$ (total plastic strain to failure). The result of differentiating the Arrhenius rate equation with regard to temperature is

$$
\mathrm{d}\left[\ln \left(\frac{1}{\Delta \epsilon_{\mathrm{p}} \mathrm{N}}\right)\right]=\frac{\mathrm{Q}}{\mathrm{RT}^{2}}
$$

from which it is seen that

$$
\mathrm{K}=\frac{\mathrm{Q}}{\mathrm{R}}=\mathrm{T}_{\mathrm{m}}\left[\frac{\mathrm{T}_{2}}{\mathrm{~T}_{2}-\mathrm{T}_{\mathrm{m}}}\right]\left[\ln \left(\alpha \Delta \mathrm{T}_{1} \mathrm{~N}_{1}\right)-\ln \left(\Delta \epsilon_{\mathrm{p}_{2}} \mathrm{~N}_{2}\right)\right]
$$

where $\mathrm{T}_{\mathrm{m}}=$ mean temperature of cycling, and $\alpha=$ coefficient of thermal expansion.

The limits at boundary 2 are subject to debate, and the procedure for handling equation 7 is presently uncertain. Therefore, Coffin's equation can still be considered as yielding "master fatigue curves" under general conditions. When comparison between test conditions is desired, however, it becomes necessary to determine the different values of $\mathrm{K}$ and $\mathrm{C}$. $^{5}$

\section{New Specimen Design}

It was noted in the last quarterly progress report ${ }^{6}$ that a discrepancy existed between the results of TSF testing at ATL and at the University of Alabama on 304 stainless steel. The ATL data gave more conservative results (see Figure 7 of ATL-A-133), since plastic strain was measured over a 2-inch gage length. The University of Alabama $\Delta \epsilon_{\mathrm{p}}$ results were accurately determined (by optical means) over a 1-inch gage length, 
and recently Majors ${ }^{4}$ has used a $\frac{1}{2}$-inch gage length for determining $\Delta \epsilon_{\mathrm{p}}$. Gage length has an effect on $\Delta \epsilon_{p}$ primarily because of the axial temperature gradient. Realizing this, . ATL has been obtaining simultaneous values of $\Delta \epsilon_{\mathrm{p}}$ for both 2-inch and $\sim 0.4$-inch gage lengths in order to assure maximum utility of program results. It has been found that plastic strain.over a 0.4 -inch gage length is $2 \frac{1}{2}$ to 4 times greater than that occurring over a 2-inch gage length in a given test. More complete results of gage lengthtemperature gradient effects will be published at a later date.

The obvious desire to have uniform temperature in the gage length, and to have the instrumentation present in the exact region of failure, has led ATL to investigate the possibility of using a new specimen design. A particular design that immediately suggests that there would be no temperature gradient in the gage length, since the axial gage length approximates zero, and that the instrumentation can be placed in the exact region of failure is shown in Figure 6. In this TSF specimen, an axial, cylindrical hole is present which results in a 0.020 -inch wall thickness at the minimum cross-sectional area. The elongationcontraction movements would be measured radially (herein called diametral strain) at the minimum diameter. There was some doubt about the state of stress at the minimum diameter, and also as to whether strain could be calculated from outside radial-movement measurements. Therefore, the services of the Engineering Mechanics Department at Stanford University were contracted for a theoretical stress analysis. The pertinent findings from this analysis are given below.

A general solution of the stresses present was attempted, using equilibrium equations in association with the well-known biharmonic equation $\nabla^{4} \phi=0$. (In tensor notation, these stresses are $\sigma_{r r}, \sigma_{\theta \theta}, \sigma_{z z}, \sigma_{r z}$, where $z$ is the axial direction.) It was found that solutions to the resulting equations would involve an immense amount of labor. Therefore, a numerical solution was attempted with the assumption that $\sigma_{\mathrm{zz}}=f(\mathrm{z})$ only. This assumption can be proved experimentally valid. The numerical solution yielded the following maximum values. for the various stresses in terms of $\sigma_{z z}$ (at $z=0$, i.e., at the minimum cross-sectional area): 


$$
\begin{aligned}
& \sigma_{\mathrm{rr}}=0.056 \% \text { of } \sigma_{\mathrm{zz}}, \\
& \sigma_{\theta \theta_{1}}=2.6 \% \text { of } \sigma_{\mathrm{zz}}, \\
& \sigma_{\theta \theta_{2}}=2.5 \% \text { of } \sigma_{\mathrm{zz}}, \\
& \sigma_{\theta \theta_{3}}=2.3 \% \text { of } \sigma_{\mathrm{zz}},
\end{aligned}
$$

where subscript 1 refers to the inner radius,

subscript 2 refers to the mean radius,

subscript 3 refers to the outer radius.

Thus, the assumption that uniaxial stress exists in the new specimen geometry is in maximum error by $4 \%$ in the elastic region of stress and $1.5 \%$ in the plastic region.

The foregoing analysis and the following facts support the use of the new specimen geometry:
a) Strain is maximum at $z=0$.
b) Failure will occur at $z=0$.
c) Instrumentation to measure $\Delta \epsilon_{\mathrm{p}}$ can be placed at $\mathrm{z}=0$.

Therefore, it will be strongly recommended that the new specimen geometry be used in the future. Results obtained on previous specimens can be extrapolated by performing a few comparative tests; hence, all data reported to date will still be useful. B. Structural Analysis

Every test specimen is sectioned and mounted for metallographic examination after failure, since this procedure should allow the effects of test variables on failure to be ascertained. As a base for comparison, the as-received (cold-worked) and annealed $\left(2\right.$ hours at $\left.1900^{\circ} \mathrm{F}\right)$ structures of $304-\mathrm{L}$ stainless steel are shown in Figures 7 and 8 , respectively. The extensive slip traces in the cold-worked specimen are more clearly shown in Figure 9. It is noticed that cross-slip is common in this steel. The conventional annealing treatment destroys the slip traces, as seen in Figure 10.

The effect of cyclic thermal stress on the cold-worked structure is made evident by examination of Figures $11,12,13$, and $14 .{ }^{*}$. The gross difference in grain structure

* See Appendix for explanation of test parameters. 
between Figures 12 and 14 is indicative of an "annealing" treatment caused by time at cyclic temperature. Although the specimen shown in Figure 14 was heated to a higher temperature $\left(900^{\circ} \mathrm{C}\right)$ than that shown in Figure $12\left(800^{\circ} \mathrm{C}\right)$, it was held at the higher temperature for a shorter period of time (the cycle ratio, or relative time at temperature, was $900^{\circ} \mathrm{C} / 800^{\circ} \mathrm{C}:: 42 / 370$ ). Failure was initiated in this series of tests by the propagation of surface cracks inward via both intercrystalline and transcrystalline paths. Even with a 60 -second hold time at the temperature extremes, the $900^{\circ} \mathrm{C}$ maximum-temperature test did not "anneal", as shown in Figure 15. While slip traces are not commonly seen in the non-failure regions of these tests, such markings occur near the propagating cracks due to the high strain that takes place in these regions. These slip traces are shown in Figure 16. There is some difficulty in distinguishing between narrow twin boundaries and broad slip traces as outlined by Hempel; ${ }^{11}$. consequently, it is possible that some of the markings labeled slip could actually be twin boundaries. In face-centered-cubic structures, the phenomenon of mechanical twinning does not take.place at elevated temperatures because of energy considerations. 12 This is borne out by present test results, since no noticeable increase in twin density is found after thermal-stress cycling.

TSF testing at a lower mean temperature $\left(400^{\circ} \mathrm{C}\right)$ also causes an "annealing" action to occur on cold-worked specimens, as shown in Figures 17 and 18. The specimen in Figure 18 reached the maximum temperature of only $700^{\circ} \mathrm{C}$, whereas the specimen of Figure 14 reached $900^{\circ} \mathrm{C}$ (both cycling through the same $\Delta \mathrm{T}$ ). The cycle ratio is $700^{\circ} \mathrm{C} / 900^{\circ} \mathrm{C}:: 288 / 42$, which again emphasizes the importance of time at temperature. A similar comparison is also shown by Figures 19 and 15, where the cycle ratio is $700^{\circ} \mathrm{C} / 900^{\circ} \mathrm{C}::$ : $94 / 32$.

The effect of stress on structure (or vice versa) is illustrated in Figure 20, where it is seen that the structure "annealed" during TSF testing (specimens 66 and 87) and underwent strain softening; however, the structures that were relatively unaffected by TSF testing (specimens 68 and 89 ) were strain hardened. 
Testing of previously annealed specimens evidently results in some further grain growth, as seen in Figures 21 and 22. Longer hold time did not change the structure, as evidenced by comparing Figures 21 and 23. Pure transcrystalline fracture is also shown in Figure 23. (It should be mentioned that the two cracks emanating from the remains of the spot-welded thermocouple were not noticed in other specimens.) Testing at a higher mean temperature $\left(600^{\circ} \mathrm{C}\right)$ again caused less "annealing", i.e., grain growth, as seen by comparing Figures 24 and 23 .

It was mentioned in the last quarterly progress report ${ }^{6}$ that. TSF-cycled specimens appeared to have broader grain boundaries than both as-received (cold-worked) and annealed materials. This difference was also observed between cold-worked specimens which "annealed" during testing and those which did not (see Figures 18 and 14, respectively). An enlargement of Figure 18 is shown in Figure 25. It is apparent that carbide precipitation is the cause of some of the gross etching of grain boundaries. Also, it appears that carbide precipitation takes place at twin boundaries; however, the etch pits at the twin ends are no doubt merely an energy-accelerated process. It is not certain whether the twins actually stop at these points or whether their angle relative to the surface is such that they submerge below the surface. An even clearer indication of carbide precipitation, and perhaps grain-boundary migration, is shown in Figure 26 (the region shown here was also seen in Figure 24).

The concurrent tests of strain cycling at constant temperature have resulted in predictable structures. For example, in Figure 27, both the "annealed" and the cold-worked structures appear to exist; whereas in a specimen undergoing greater plastic strain per cycle at a higher temperature (Figure 28) the "annealed" appearance is everywhere evident. The total time at temperature was approximately 5 times greater in Figure 27 than in Figure 28; thus, it was noted that the $400^{\circ} \mathrm{C}$ temperature was too low to effect "annealing". The cold-worked structure is still present in specimens that were held for long lengths of time (60-second hold time) at temperatures of $400^{\circ} \mathrm{C}$; however, a relatively small amount of plastic strain per cycle resulted (see Figure 29).

Strain cycling the annealed 304-L stainless steel has no doubt resulted in the slip whose traces are seen in Figures 30 and 31. Cross-slip is clearly evident in both these photomicrographs, as is grain-boundary carbide precipitation. 
Various investigators ${ }^{13,14}$ have reported that twin boundaries are sites for fatigue cracks in face-centered-cubic metals. Such cracking has not been observed in the structures examined to date by ATL. Another reported phenomenon is the creation of voids, especially in grain boundaries, as a result of fatigue testing. ${ }^{11}$ There are two causes for void formation: grain-boundary sliding (or grain rotation), and dislocation climb followed by vacancy migration condensation. Void formation has been generally observed in the tests at ATL as evidenced by Figures 14, 24, 31, and 32 . As yet, a study has not been performed on the test criteria for void formations; hence, this subject cannot be elaborated on further. It is worthwhile to mention, however, that it is troublesome to distinguish between grain-boundary carbides and voids. Clearly, it is possible for carbides to become unbonded during polishing, leaving a cavity that can be mistaken for a void formed by vacancy agglomeration. 


\section{PLANS FOR FUTURE WORK}

Both TSF and SC testing will continue on 304-L stainless steel. The next major variable to be studied will be the effect of very large grain size as compared to the as-received and annealed grain sizes. It is expected that the smaller grain-boundary area will weaken the specimens at higher temperatures.

A meeting will be held with the U.S. Atomic Energy Commission to decide upon the next material for testing and whether major emphasis will be placed on the proposed new specimen design.

\section{CONCLUSIONS}

1) The effect of cold work is manifested in a longer fatigue life than shown by annealed material at low-cycle-fatigue conditions and a shorter fatigue life at highcycle-fatigue conditions. The cause for this is probably the lack of strain softening of as-received material at low-cycle-fatigue test conditions.

2) An effect of hold time at temperature extremes is not evident on graphs of $\Delta \epsilon_{\mathrm{p}}$ versus $\mathrm{N}$, whereas an effect is evident on graphs of hold time versus $\mathrm{N}$. The reason for the former is the dependence of the $\Delta \epsilon_{p}$ variable, since increasing hold time increases $\Delta \epsilon_{\mathrm{p}}$ (per cycle).

3) Atmospheric effects have not been seen to date. It is not certain if this is a valid general conclusion because the study is still incomplete.

4) The variable $\Delta \epsilon_{\mathbf{p}}$ : has been shown to be dependent on extraneous conditions. This implies that any parameter that attempts to predict fatigue life should include $\Delta \epsilon_{\mathrm{p}} \operatorname{directly}$.

5) The "annealing" that takes place during TSF testing merely distinguishes between two obviously different structures. The primary differences between the two structures are: a) widths of the grain boundaries, b) presence of voids at grain boundaries, and c) difference in the grain shape (rounded as compared to irregular). It is highly possible that dislocation motion toward grain boundaries by both slip and climb mechanisms. is responsible for the first two differences and that grain rotation and boundary migration are responsible for the third difference. 


\section{REFERENCES}

1. L. F. Coffin, Jr., "A Study of the Effects of Cyclic-Thermal Stresses on a Ductile Metal," Trans. ASME, August 1954.

2. F. J. Mehringer and R. P. Felgar, "Low-Cycle Fatigue of Two Nickel-Base Alloys by Thermal-Stress Cycling," Trans. ASME, Series D, September 1960.

3. A. E. Carden and J. A. Sodergren, "The Failure of 304 Stainless Steel by ThermalStrain Cycling at Elevated Temperatures, " ASME Preprint, 1961.

4. H. Majors, Jr., "Correlation of Thermal Fatigue with Mean Temperature and Influence of Combined Stress," Seattle University, March 1962.

5. K. E. Horton and R. S. Stewart, "Thermal-Stress-Fatigue Behavior of Zirconium and Zirconium Alloys, "Advanced Technology Laboratories, Final Report ATL-A-127, 31 October 1961.

6. K. E. Horton, "Investigation of Thermal-Stress-Fatigue Behavior of Stainless Steels," Advanced Technology Laboratories, Quarterly Progress Report No. 3, ATL-A-133, July-September 1962 .

7. A. E. Carden, University of Alabama, Private communication.

8. F. R. Larson and J. Miller, "A Time-Temperature Relationship for Rupture and Creep Stresses," Trans. ASME, July 1952.

9. C. E. Feltner and J. Morrow, "Micro-Plastic Strain Hysteresis Energy as a Criterion for Fatigue Fracture," ASME Preprint, 1960.

10. S. Goldfein; "Theory for Mechanical-Chemical Equation of State," Materials Research and Standards, November 1962.

11. M. R. Hempel, "Slip Bands, Twins, and Precipitation Processes in Fatigue Strèssing," Fracture, New York, John Wiley \& Sons (1959).

12. C. S. Barrett, "Symposium on Imperfections in Nearly Perfect Crystals,". New York, John Wiley \& Sons (1952).

13. C. A. Stubbington and F. J. Forsyth, J. Inst. Metals, 86, p 90 (1957).

14. D. S. Kemsley, J. Inst. Metals, $\underline{85}$, p 153 (1956). 


\section{REPORTS ISSUED SINCE INCEPTION OF PROGRAM}

Quarterly Technical Progress Report, January-March 1962, ATL-A-130, EURAEC 336 Quarterly Technical Progress Report, April-June 1962, ATL-A-131, EURAEC 335 Quarterly Technical Progress Report, July-September 1962, ATL-A-133, EURAEC 481 


\section{TABLE I}

TSF AND SC TEST CONDUCTED DURING QUARTER

(See Appendix for explanation of test parameters.)

Specimen No.

59

38

61

69

70

71

72

73

62,52

63

64

65

66

67

68

35

37,41

38

39

40

49
Test

I.A. $1 . a \cdot \underline{1} \cdot$ a) $-1 d$

I. A. 1.b. 1 . a) $-2 b$

I. A. 1.a.1. a) $-3 d$

I. A. 1.b. 1 . a) $-3 a$

I. A. 1.b. 1 . a) $-3 b$

I. A. 1.b. $\frac{1}{1}$. a) $-2 \mathrm{c}$

I. A. 1.b. 1 . a) $-1 d$

I. A. 1.b. $\overline{1}$. a) $-3 \mathrm{c}$

I. A. 1.a. 1. f) $-1 \mathrm{a}$

I. A. 1.a. 1 . e)-1a

I. A. 3.a. 1 . c) -3 b

I. A. 3.a. 1 .c)-3c

I. A. 3.a. 1 . c) $-1 d$

I. A. 3.a. 1 . c) -1c

I. A. 3.a. $\overline{1}$. c) $-3 \mathrm{~d}$

I. A. 1.a. 1 .f) $-3 b$

I. A. 1.b. 1 . c) $-1 d$

I. A. 1.b. 1. a)-1b

I. A. 1.a. 1 . a) $-3 b$

I. A: 1 . a. 1 . a) $-3 \mathrm{c}$

I. A. 1.a. 1 . a) -1 b
Specimen No.

$\underline{\text { Test }}$

\begin{tabular}{|c|c|}
\hline 50 & I. A. 1. b. $1 . \cdot c)-3 b$ \\
\hline 54 & I. A. $1 \cdot a \cdot \overline{1} \cdot$ a) $-1 \mathrm{c}$ \\
\hline 56 & I. A. 1.a. 1. c) $-3 b$ \\
\hline 57 & I. A. $1 \cdot a \cdot \underline{1} \cdot c)-3 c$ \\
\hline 58 & I. A. 1.a. 1 . a)-3a \\
\hline 74 & I.A. 1. a. $1 . f)-1 \mathrm{c}$ \\
\hline 81 & I. A. 3.a. 1 .e $)-1 \mathrm{a}$ \\
\hline 82 & I. A. 3.a. $\underline{1} \cdot f)-1 \mathrm{c}$ \\
\hline 83 & I. A. 3.a. $\underline{1} \cdot f)-1 \mathrm{a}$ \\
\hline 85 & I.A.3.a. $\underline{1} \cdot \mathrm{e})-3 \mathrm{~b}$ \\
\hline 88 & I. A. 3.a. $\underline{1} \cdot$ e) $-1 \mathrm{c}$ \\
\hline 80 & I.A.3.a. $1 . a)-3 b$ \\
\hline 84 & I. A. 3.a. 1 .a) $-3 \mathrm{c}$ \\
\hline 86,94 & I. A. 3.a. 1. a)-1c \\
\hline 87 & I. A. 3.a. 1 .a) $-1 \mathrm{~d}$ \\
\hline 89 & I. A. 3.a. 1 , a)-3d \\
\hline 91 & I. A. 3.a. 1 . a) $-3 \mathrm{a}$ \\
\hline 92 & I. A. 3.b. $\overline{1} \cdot a)-1 c$ \\
\hline 93 & I. A. 3.a. $\overline{1} \cdot a)-1 b$ \\
\hline 42 & I. B. 1.b. \\
\hline 43 & I. B. 1.a. $\left.\underline{1}_{0} \mathrm{c}\right)-3 \mathrm{a}$ \\
\hline
\end{tabular}




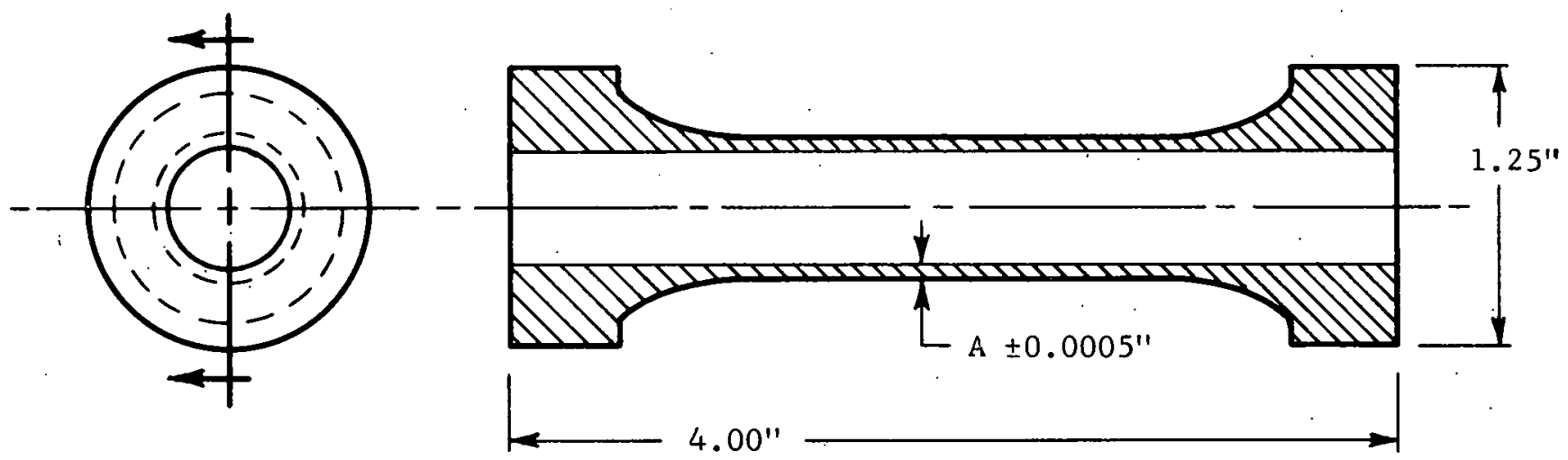

\begin{tabular}{|c|c|}
\hline DASH NO. & DIMENSION A \\
\hline-1 & $0.020^{\prime \prime}$ \\
\hline-2 & $0.030^{\prime \prime}$ \\
\hline
\end{tabular}

CONVENTIONAL TSF TEST SPECIMEN

FIGURE 1 


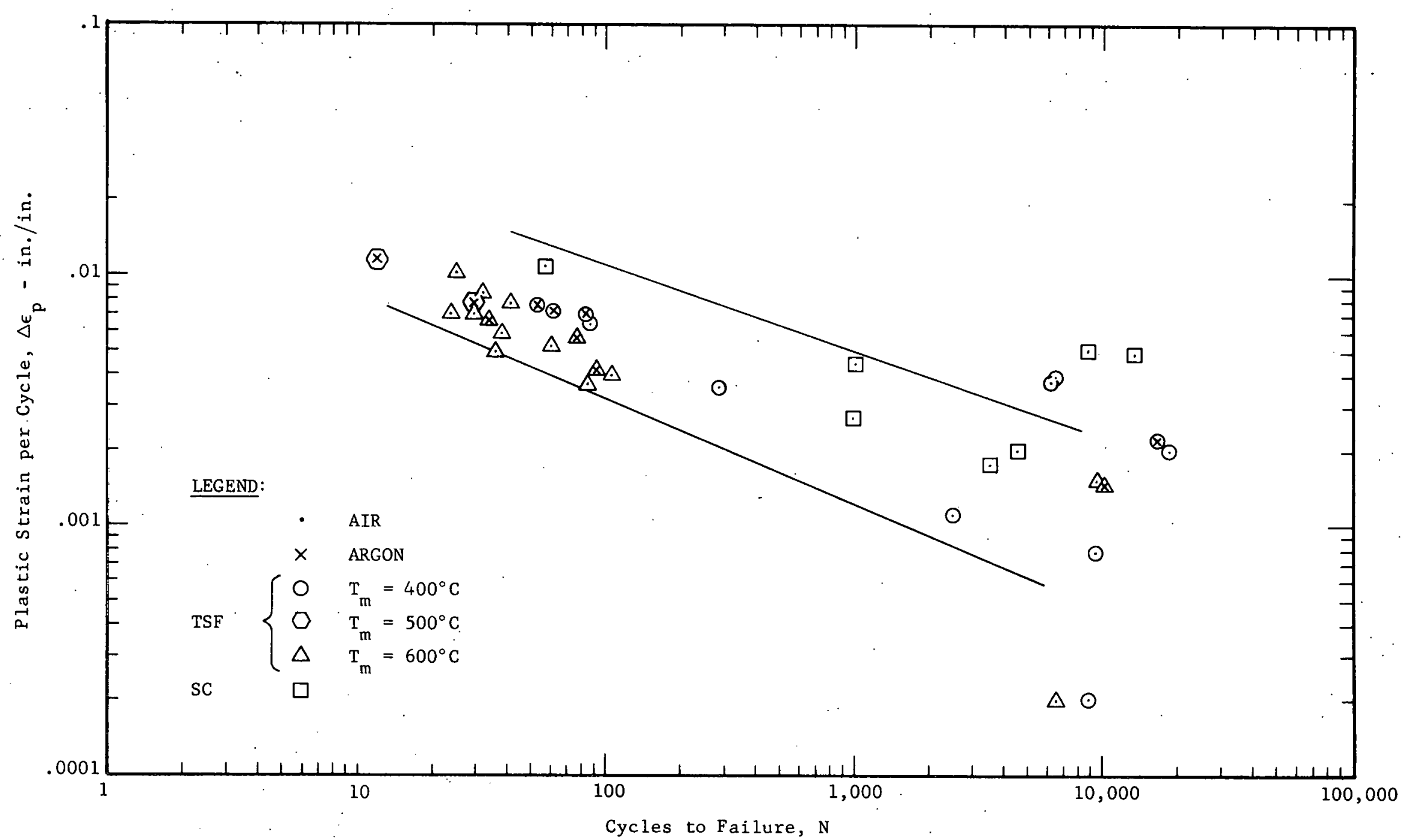

SUMMARY OF RESULTS OF TESTS ON ANNEALED AND

COLD-WORKED 304-L STAINLESS STEEL, SHOWING

PLASTIC STRAIN PER CYCLE VERSUS CYCLES TO FAILURE

FIGURE 2 


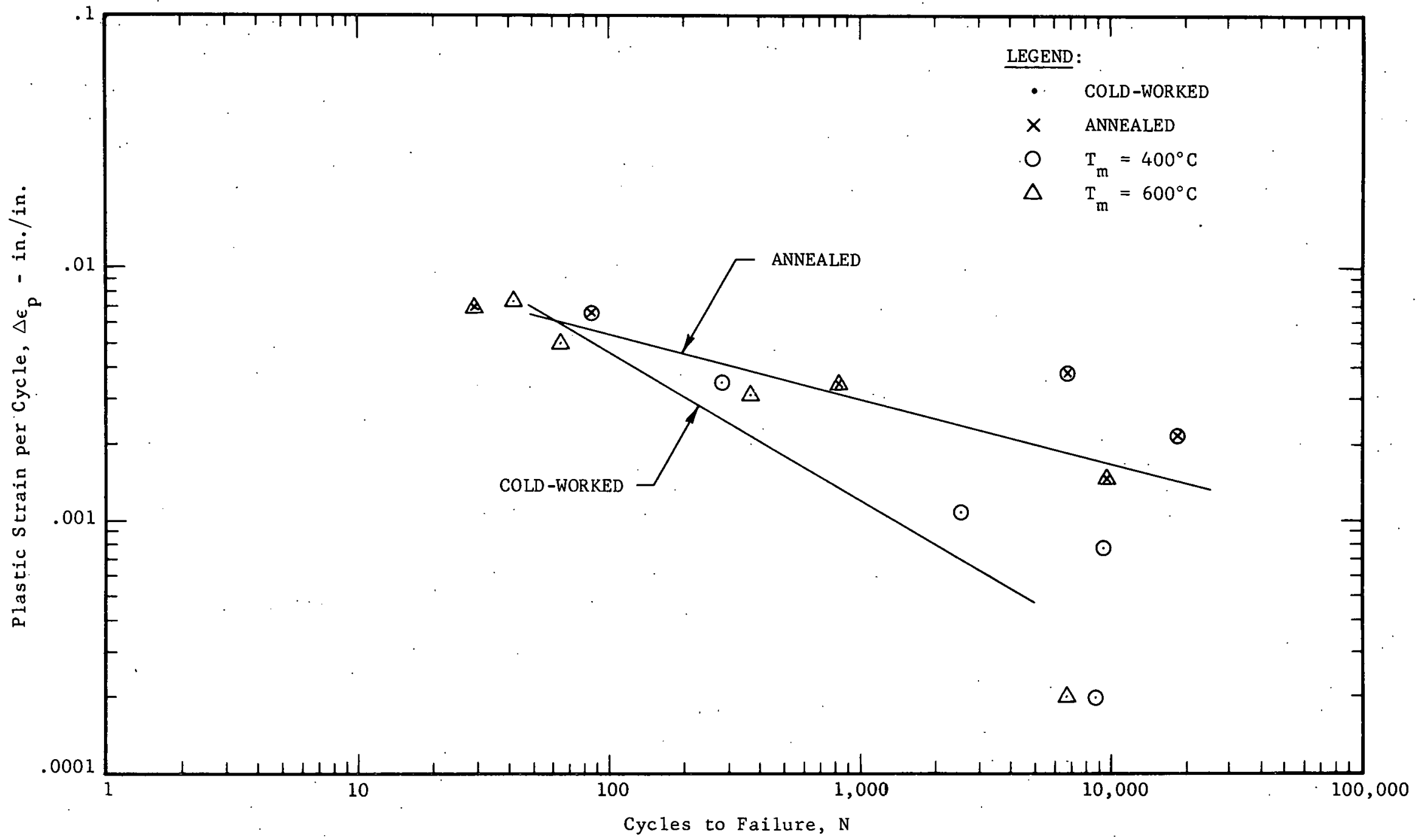

PLASTIC STRAIN PER CYCLE VERSUS CYCLES TO FAILURE FOR ANNEALED AND COLD-WORKED 304-L STAINLESS STEEL TESTED IN AIR, SHOWING EF FECT OF COLD WORK 


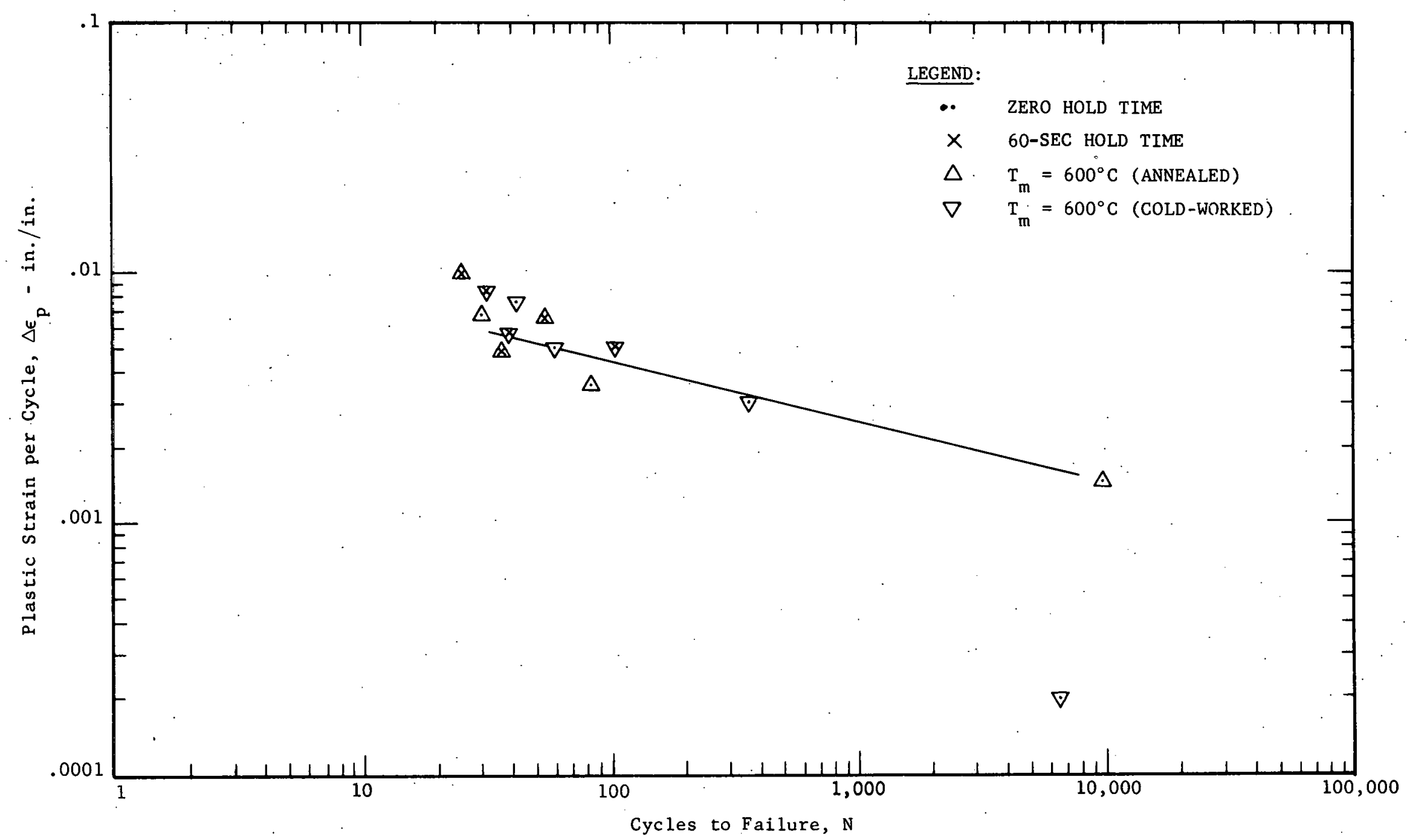

PLASTIC STRAIN PER CYCLE VERSUS CYCLES TO FAILURE FOR ANNEALED AND COLD-WORKED 304-L STAINLESS STEEL TESTED IN AIR, SHOWING EFFECT OF HOLD TIME

FIGURE 4 


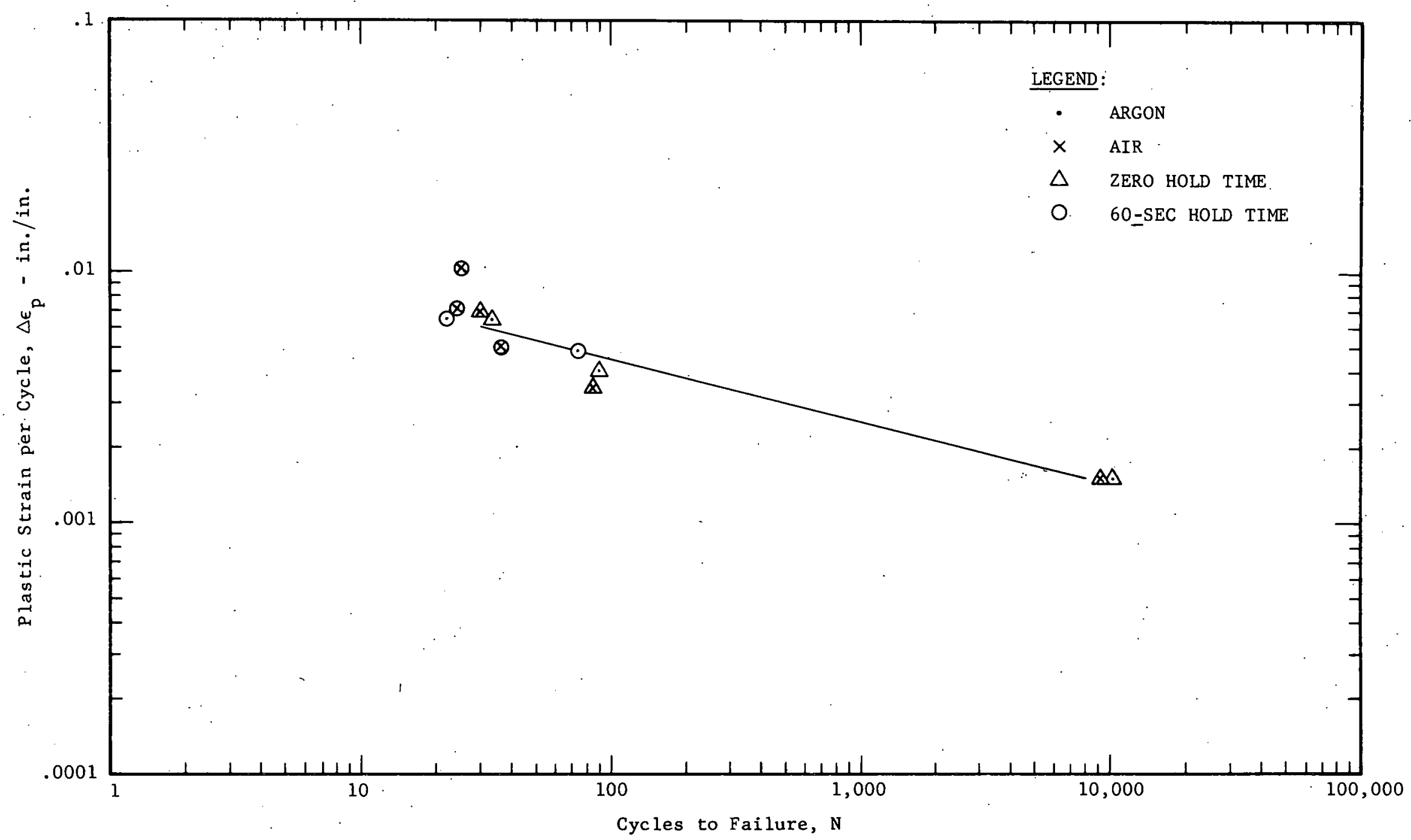

PLASTIC STRAIN PER CYCLE VERSUS CYCLES TO FAILURE FOR ANNEALED 304-L STAINLESS STEEL SHOWING EFFECT OF SURROUNDING ATMOSPHERE

$\left(\mathrm{T}_{\mathrm{m}}=600^{\circ} \mathrm{C}\right)$

FIGURE 5 


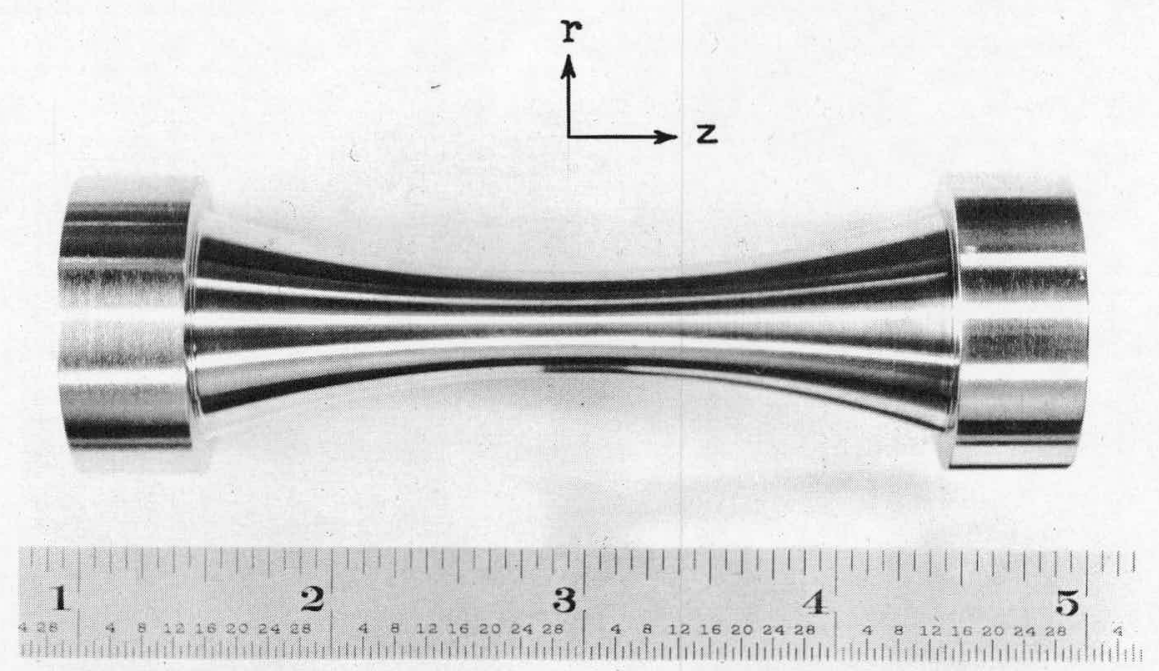

Neg. \#4495

PROPOSED NEW SPECIMEN DESIGN

(An axial, cylindrical hole runs entirely through the specimen.)

FIGURE 6 


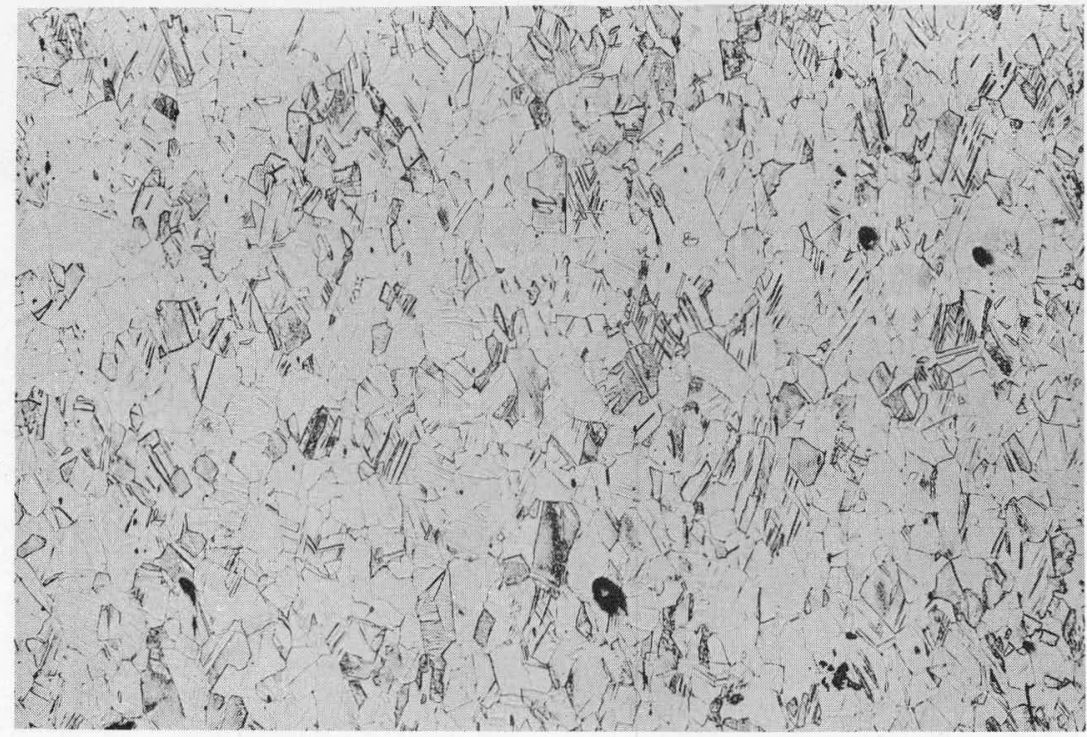

Neg. \#4363

\section{AS-RECEIVED (COLD-WORKED) TYPE 304-L STAINLESS STEEL Electrolytic Etch: 10\% Oxalic Acid}

\section{FIGURE 7}

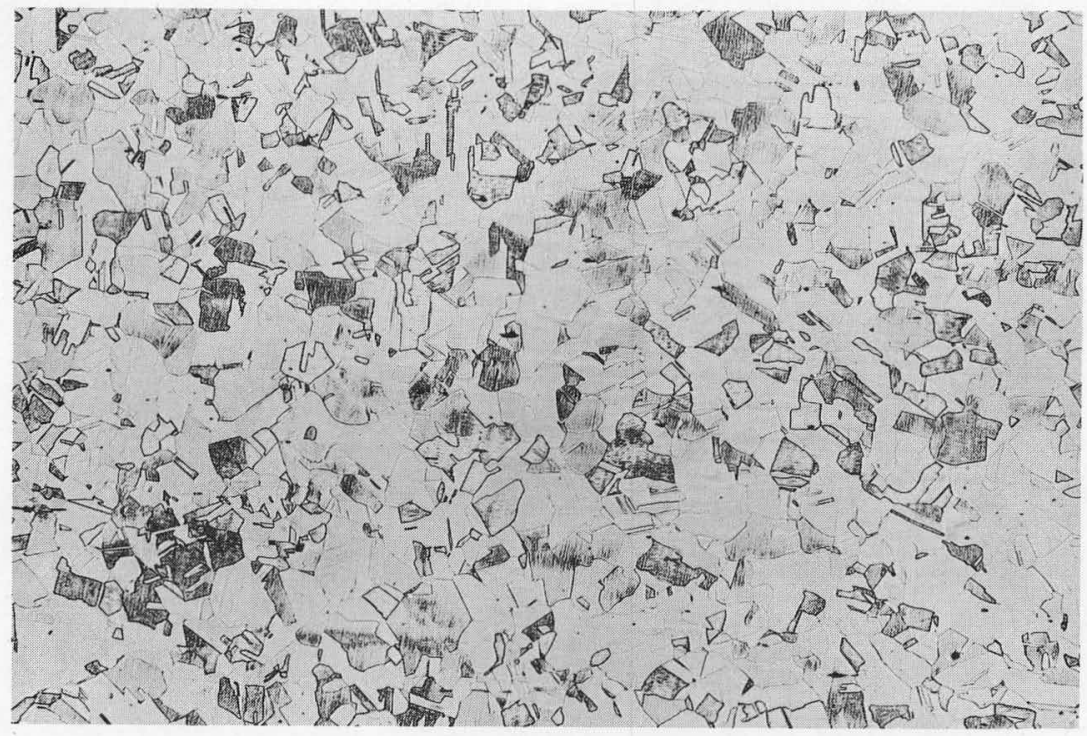

Neg. \#4377

TYPE 304-L STAINLESS STEEL ANNEALED 2 HOURS AT $1900^{\circ} \mathrm{F}$ Electrolytic Etch: 10\% Oxalic Acid 


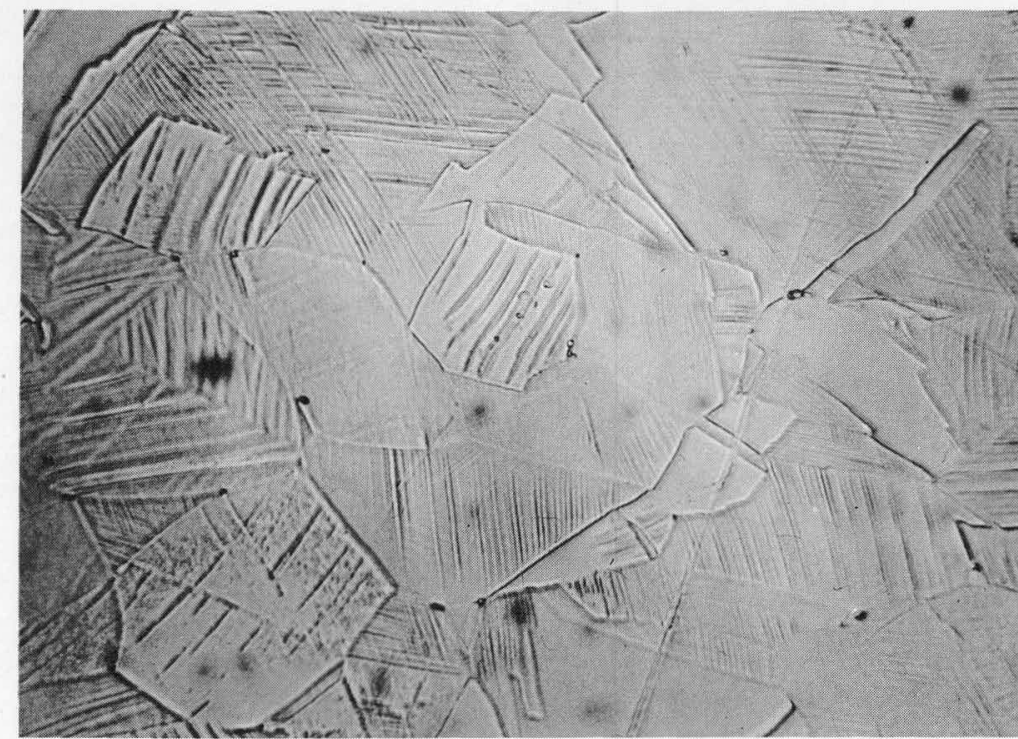

$750 x$

Neg. \#4640

\section{COLD-WORKED TYPE 304-L STAINLESS STEEL SHOWING SLIP STRACES \\ Electrolytic Etch: 10\% Oxalic Acid}

FIGURE 9

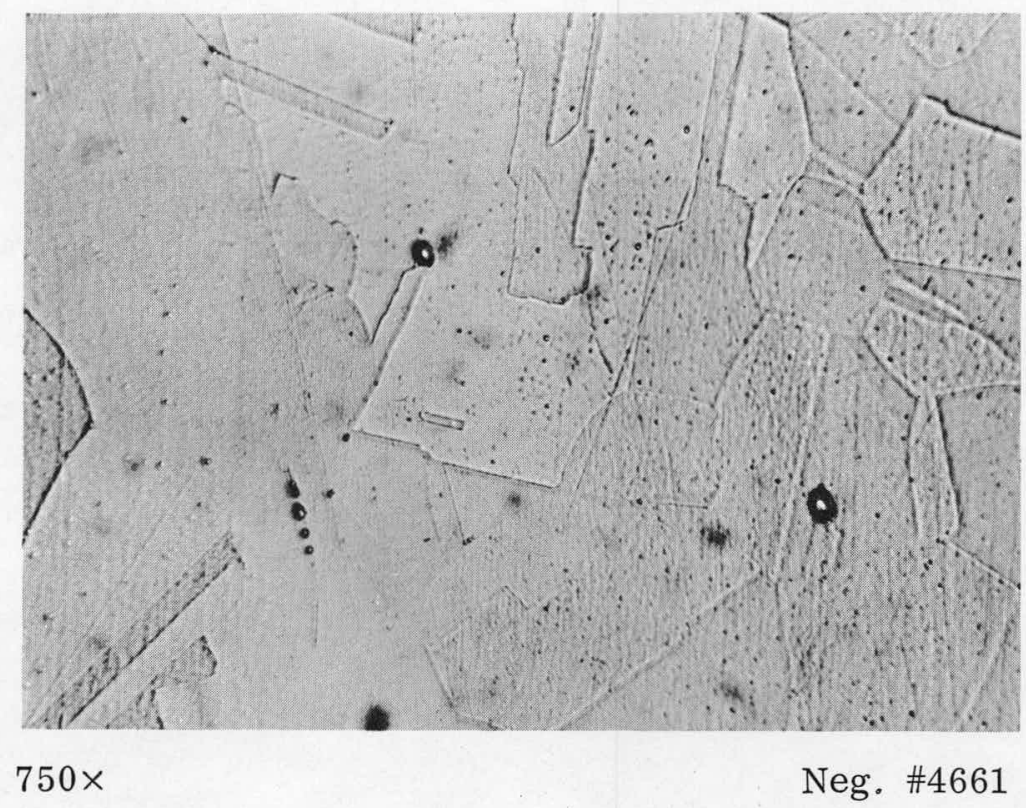

\footnotetext{
COLD-WORKED TYPE 304-L STAINLESS STEEL SHOWING DESTRUCTION OF SLIP TRACES BY 2 -HOUR ANNEAL AT $1900^{\circ} \mathrm{F}$

Electrolytic Etch: 10\% Oxalic Acid
} 


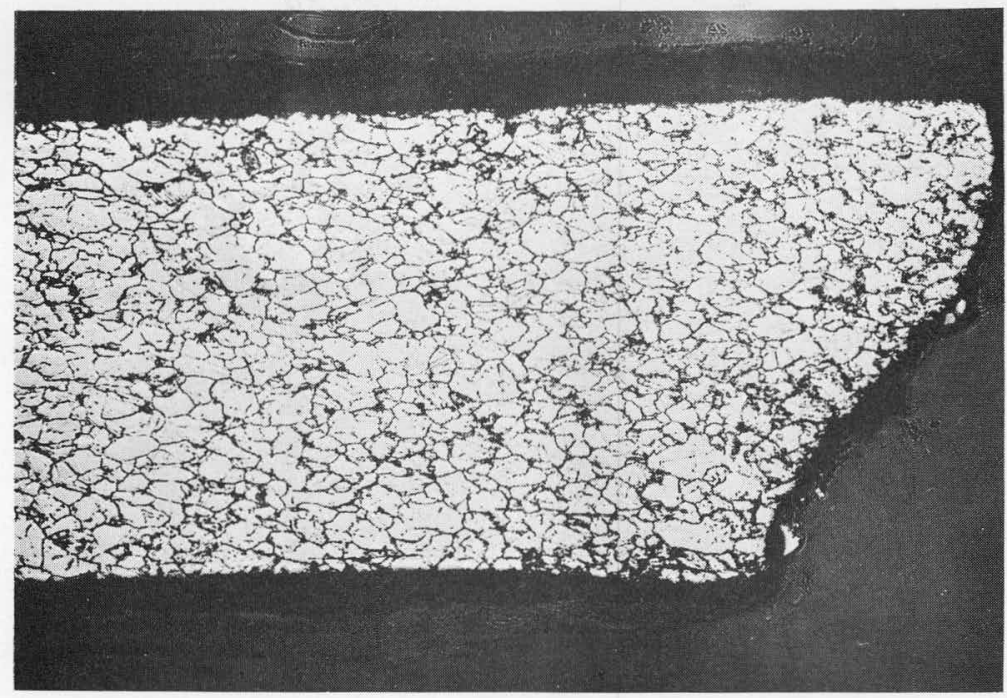

$100 \times$

Neg. \#4635

SPECIMEN 91. TEST I. A. 3.a. 1. a)-3a

$\mathrm{T}_{\mathrm{m}}=600^{\circ} \mathrm{C}, \Delta \mathrm{T}=200^{\circ} \mathrm{C}$

Electrolytic Etch: $10 \%$ Oxalic Acid

FIGURE 11

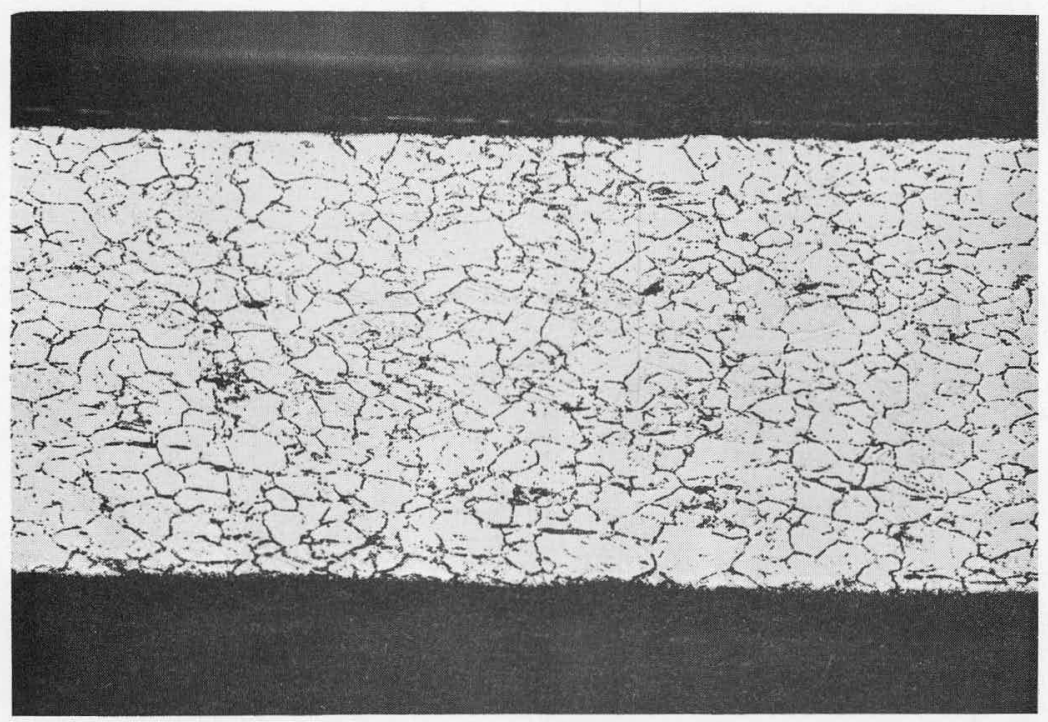

$100 \times$

Neg. \#4636

SPECIMEN 80. TEST I. A. 3.a. 1 . a) -3b

$\mathrm{T}_{\mathrm{m}}=600^{\circ} \mathrm{C}, \Delta \mathrm{T}=400^{\circ} \mathrm{C}$

Electrolytic Etch: $10 \%$ Oxalic Acid

FIGURE 12 


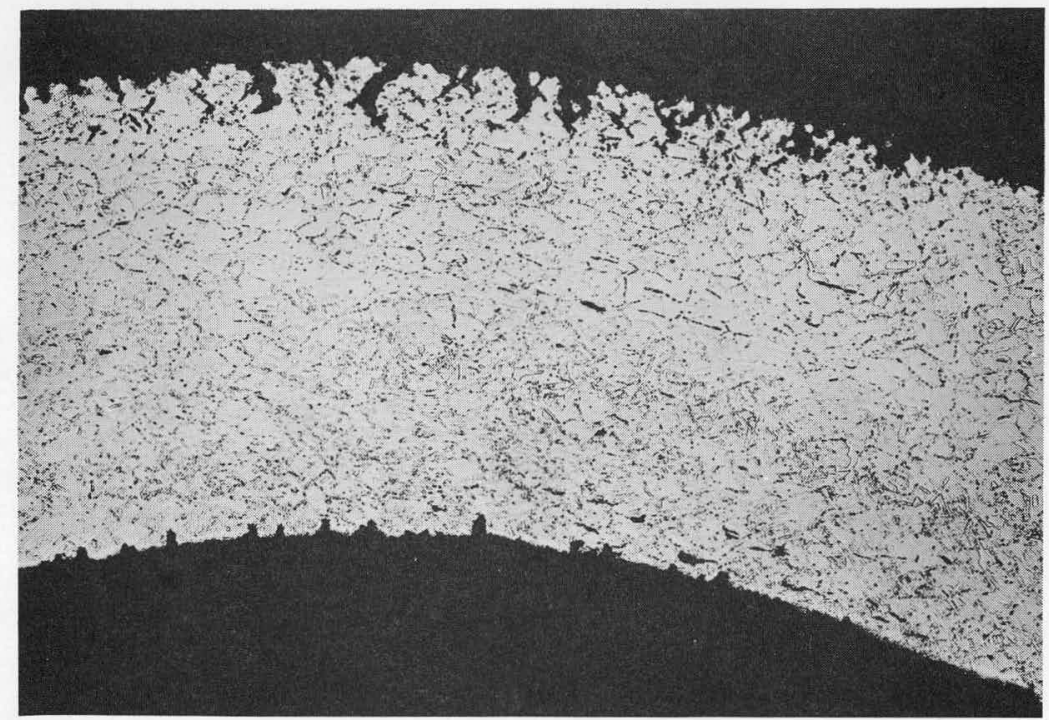

SPECIMEN 84. TEST I.A. 3. a. 1. a)-3c

$\mathrm{T}_{\mathrm{m}}=600^{\circ} \mathrm{C}, \Delta \mathrm{T}=500^{\circ} \mathrm{C}$

Electrolytic Etch: 10\% Oxalic Acid

FIGURE 13

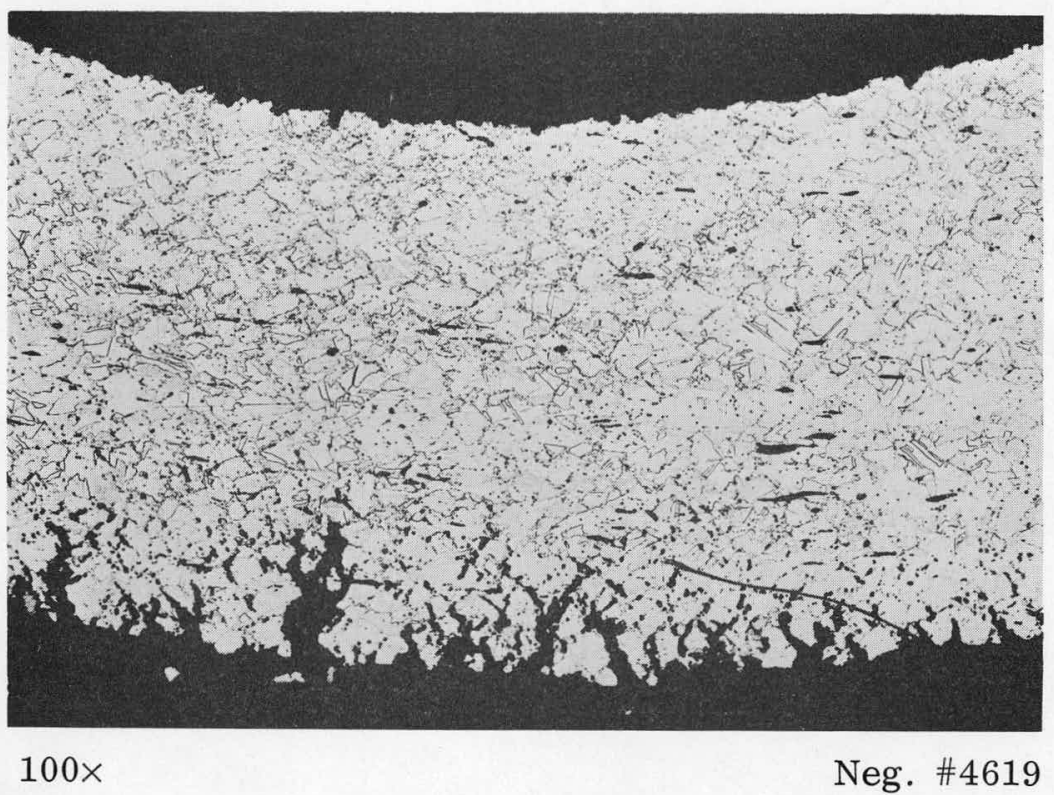

SPECIMEN 89. TEST I. A. 3. a. 1. a)-3d

$\mathrm{T}_{\mathrm{m}}=600^{\circ} \mathrm{C}, \Delta \mathrm{T}=600^{\circ} \mathrm{C}$

Electrolytic Etch: $10 \%$ Oxalic Acid 


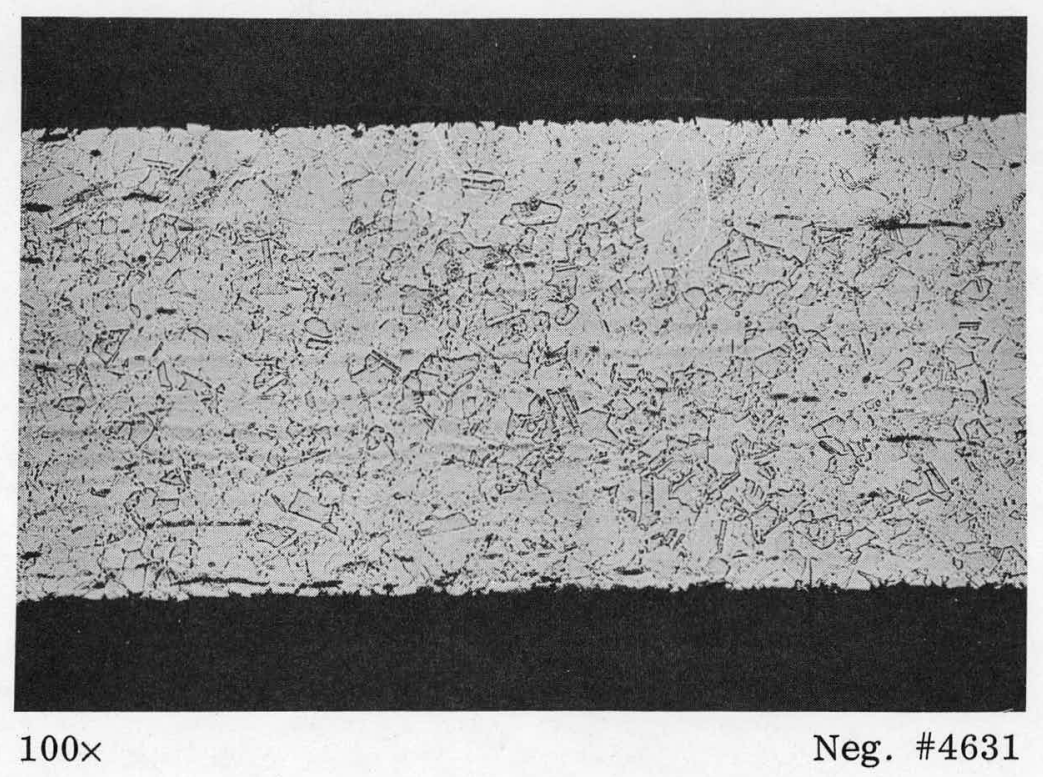

SPECIMEN 68. TEST I. A. 3. a. 1. c)-3d

$\mathrm{T}_{\mathrm{m}}=600^{\circ} \mathrm{C}, \Delta \mathrm{T}=600^{\circ} \mathrm{C}$

Electrolytic Etch: $10 \%$ Oxalic Acid

FIGURE 15

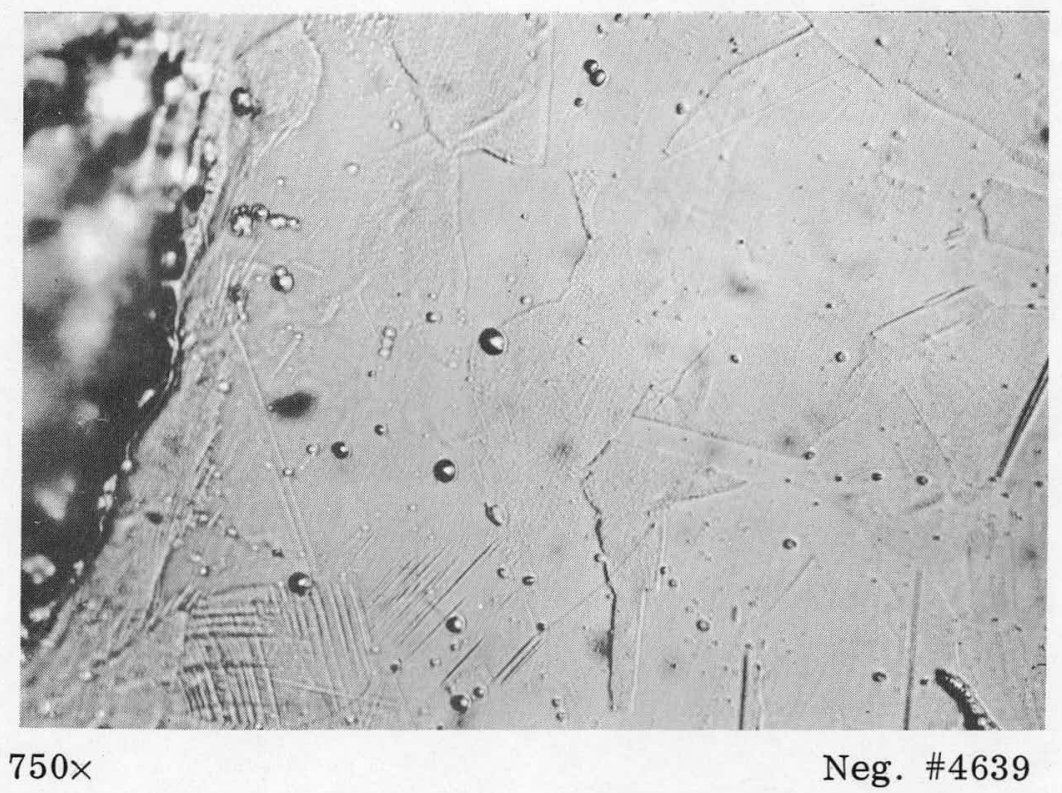

SPECIMEN 68. TEST I.A. 3. a. 1. c)-3d

SHOWING SLIP TRACES

$\mathrm{T}_{\mathrm{m}}=600^{\circ} \mathrm{C}, \Delta \mathrm{T}=600^{\circ} \mathrm{C}$

Electrolytic Etch: $10 \%$ Oxalic Acid

FIGURE 16 


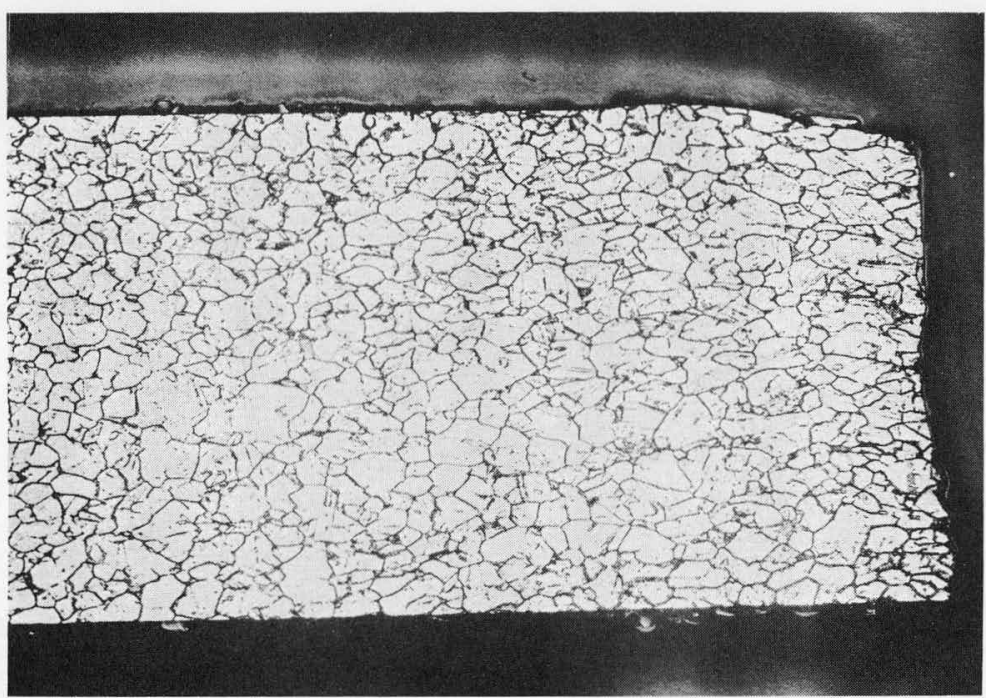

$100 \times$

Neg. \#4628

SPECIMEN 86. TEST I. A. 3.a.1. a)-1c

$\mathrm{T}_{\mathrm{m}}=400^{\circ} \mathrm{C}, \Delta \mathrm{T}=400^{\circ} \mathrm{C}$

Electrolytic Etch: $10 \%$ Oxalic Acid

FIGURE 17

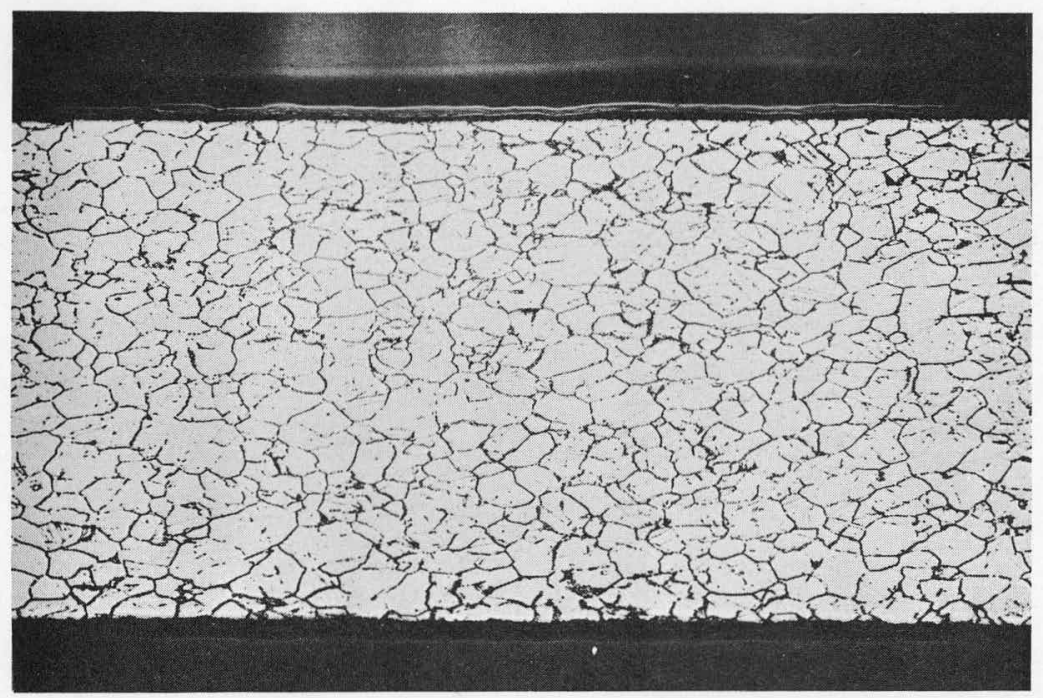

$100 \times$

Neg. \#4633

SPECIMEN 87. TEST I. A. 3.a. 1 . a)-1d

$\mathrm{T}_{\mathrm{m}}=400^{\circ} \mathrm{C}, \Delta \mathrm{T}=600^{\circ} \mathrm{C}$

Electrolytic Etch: 10\% Oxalic Acid

FIGURE 18 


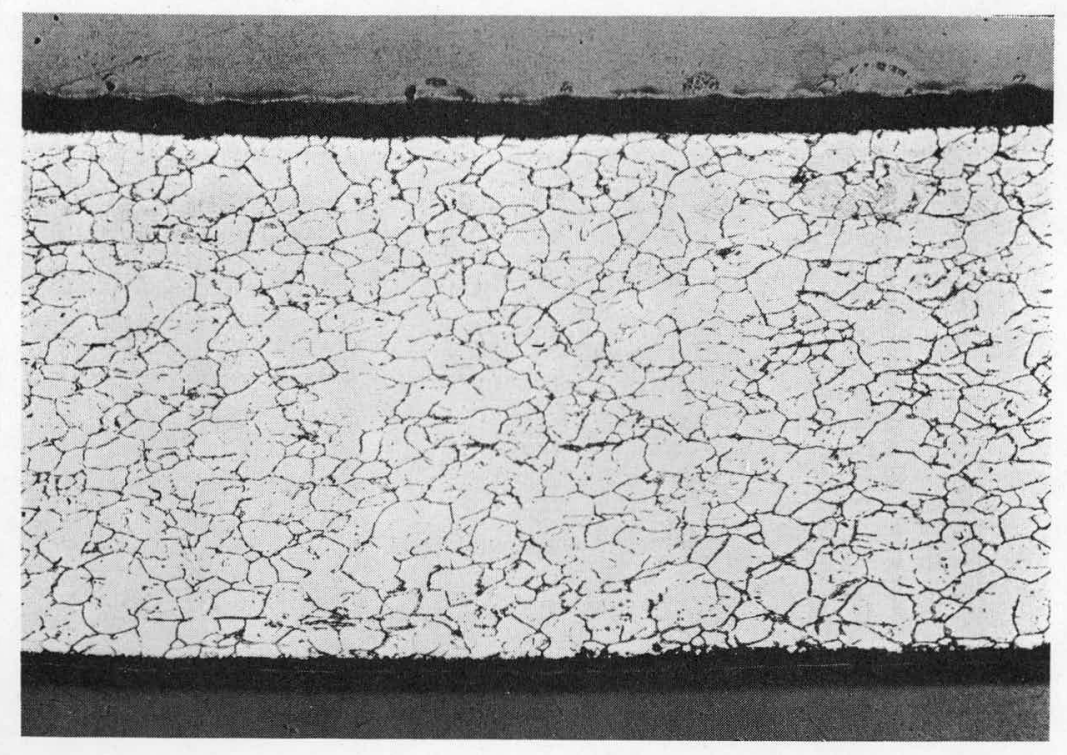

$100 \times$

Neg. \#4620

SPECIMEN 66. TEST I. A. 3.a. 1. c)-1d

$\mathrm{T}_{\mathrm{m}}=400^{\circ} \mathrm{C}, \Delta \mathrm{T}=600^{\circ} \mathrm{C}$

Electrolytic Etch: 10\% Oxalic Acid

FIGURE 19 


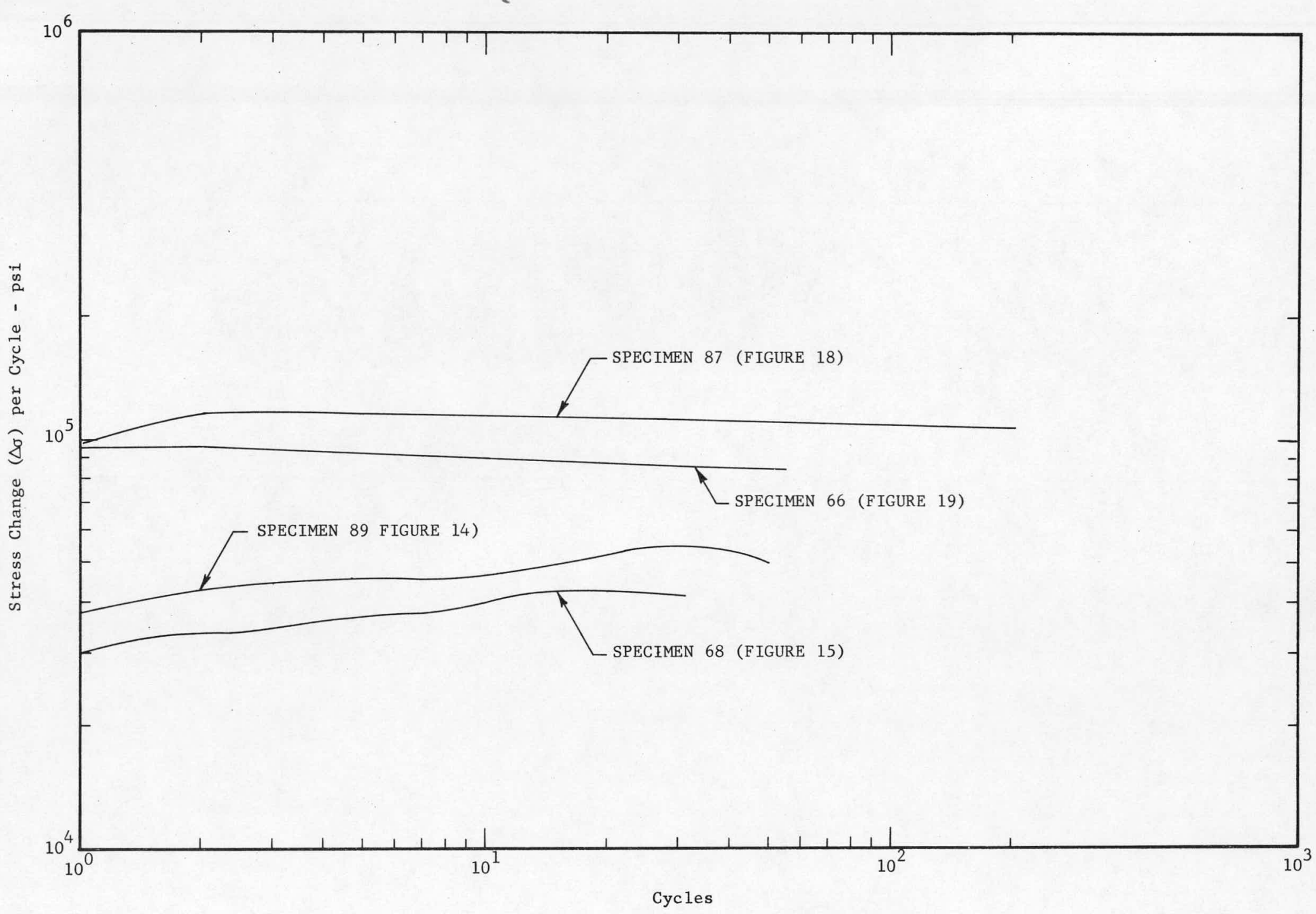

CYCLIC STRESS DURING FATIGUE TESTS

FIGURE 20 


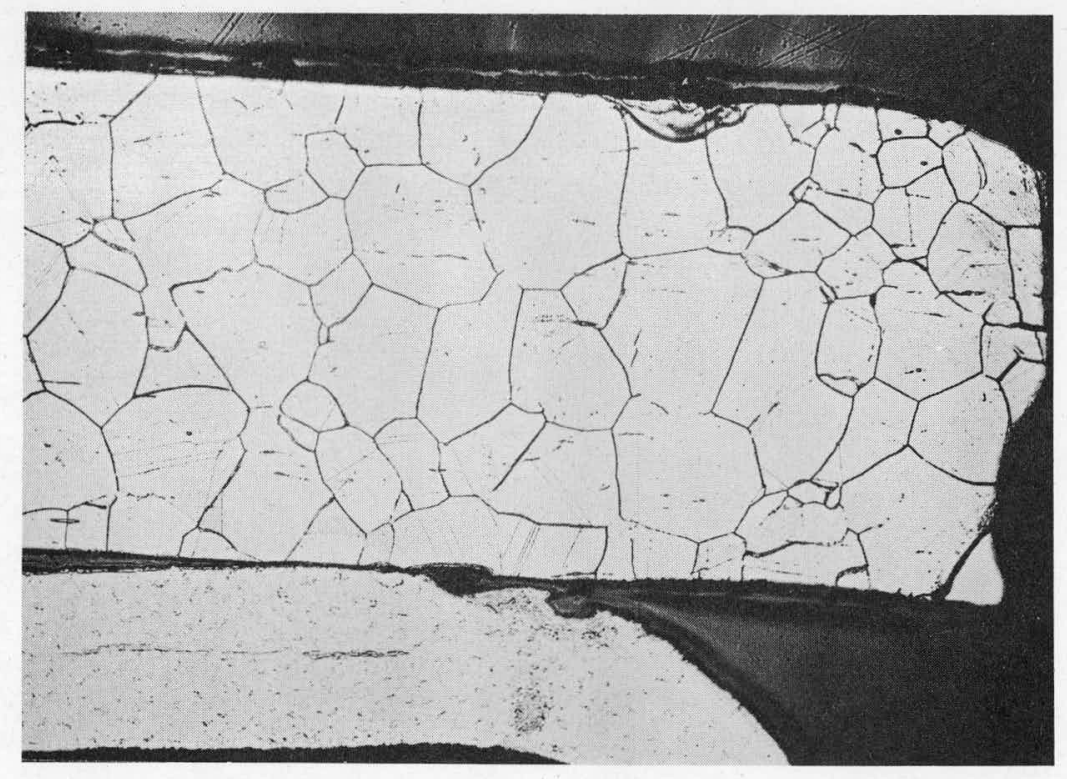

$100 \times$

Neg. \#4629

SPECIMEN 54. TEST I. A. 1. a. 1. a)-1c

$\mathrm{T}_{\mathrm{m}}=400^{\circ} \mathrm{C}, \Delta \mathrm{T}=400^{\circ} \mathrm{C}$

Electrolytic Etch: $10 \%$ Oxalic Acid

FIGURE 21

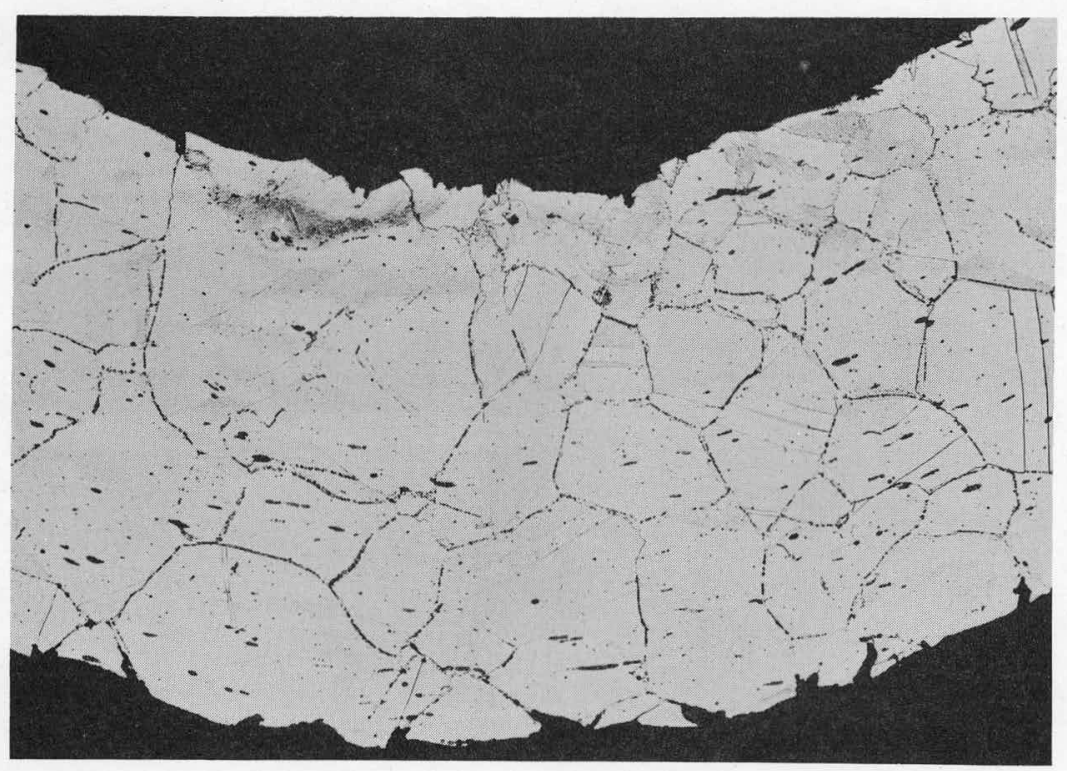

$100 \times$

Neg. \#4622

SPECIMEN 61. TEST I.A.1.a. 1 . a)-3d

$\mathrm{T}_{\mathrm{m}}=600^{\circ} \mathrm{C}, \Delta \mathrm{T}=600^{\circ} \mathrm{C}$

Electrolytic Etch: $10 \%$ Oxalic Acid

FIGURE 22 


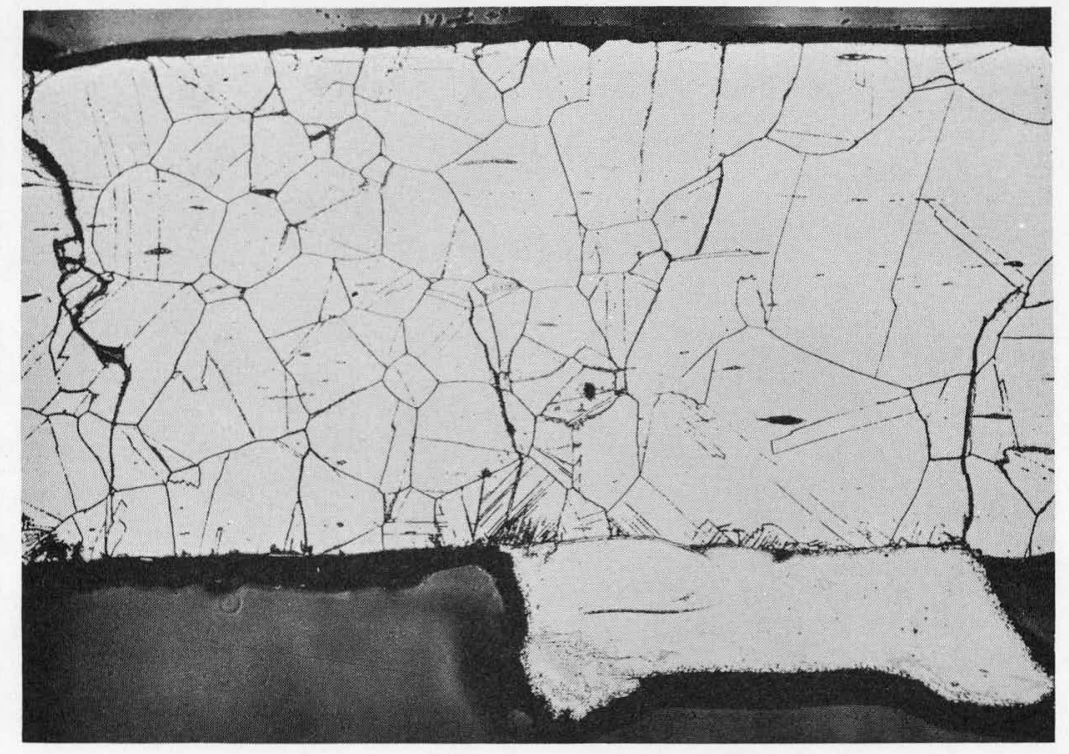

$100 \times$

Neg. \#4630

SPECIMEN 34. TEST I. A. 1.a. 1. c)-1c

$\mathrm{T}_{\mathrm{m}}=400^{\circ} \mathrm{C}, \Delta \mathrm{T}=400^{\circ} \mathrm{C}$

Electrolytic Etch: 10\% Oxalic Acid

FIGURE 23

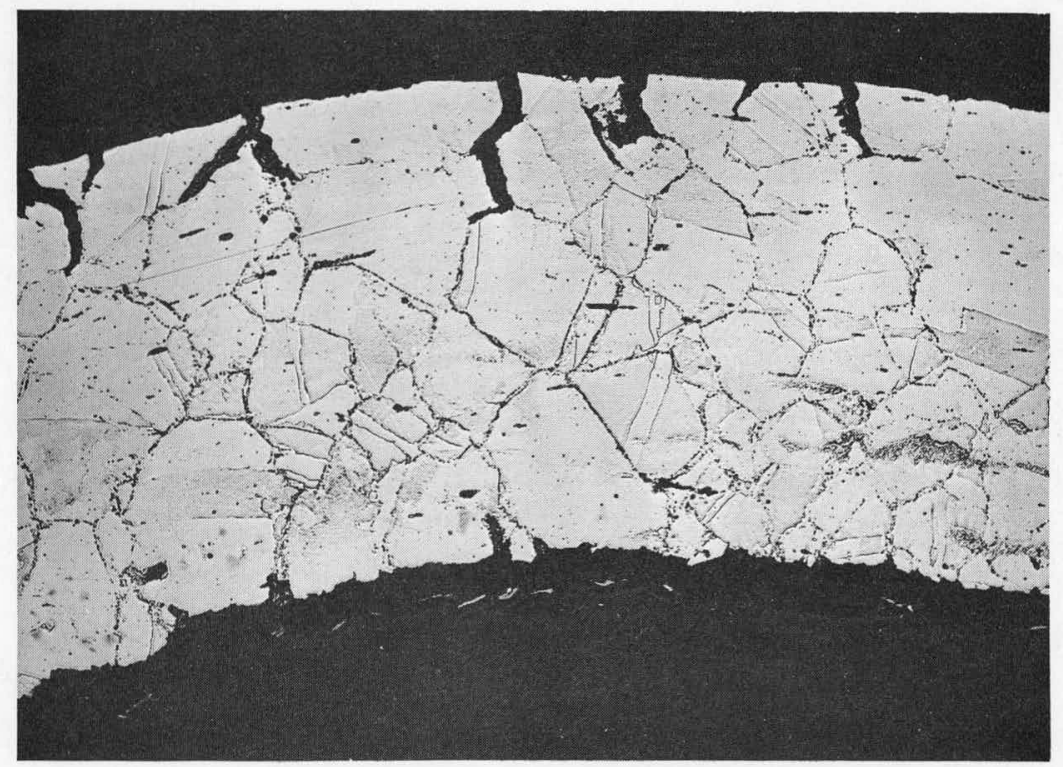

$100 \times$

Neg. \#4643

SPECIMEN 57. TEST I.A.1.a. 1 . c)-3c

$\mathrm{T}_{\mathrm{m}}=600^{\circ} \mathrm{C}, \Delta \mathrm{T}=500^{\circ} \mathrm{C}$

Electrolytic Etch: $10 \%$ Oxalic Acid 


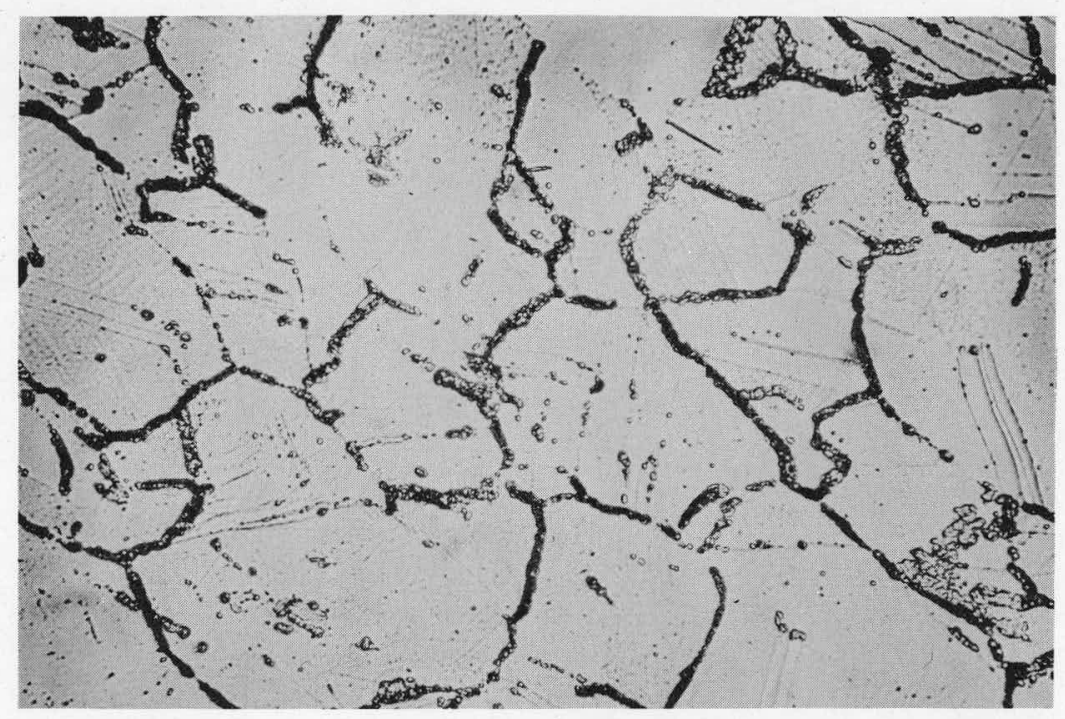

$500 \times$

Neg. \#4634

SPECIMEN 87. TEST I. A. 3.a. 1 . a) -1d $\mathrm{T}_{\mathrm{m}}=400^{\circ} \mathrm{C}, \Delta \mathrm{T}=600^{\circ} \mathrm{C}$

Electrolytic Etch: $10 \%$ Oxalic Acid

FIGURE 25

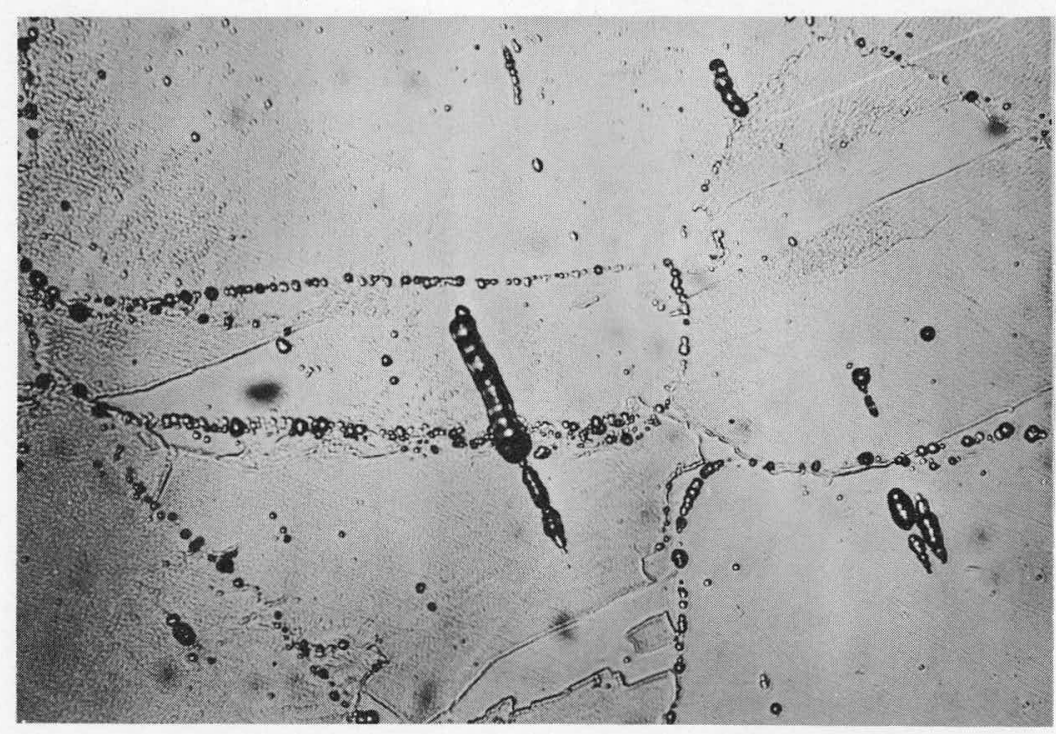

SPECIMEN 57. TEST I. A. 1. a. 1 . c) -3c

$\mathrm{T}_{\mathrm{m}}=600^{\circ} \mathrm{C}, \Delta \mathrm{T}=500^{\circ} \mathrm{C}$

Electrolytic Etch: 10\% Oxalic Acid 


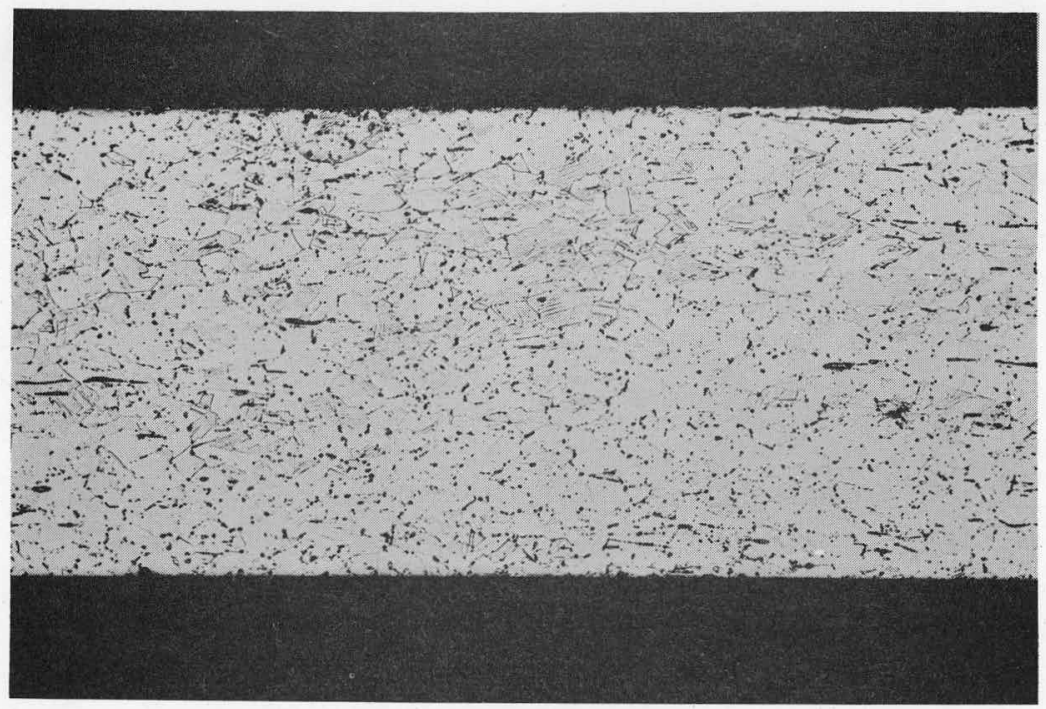

SPECIMEN 81. TEST I. A. 3. a. 1. e)-1a $\mathrm{T}=400^{\circ} \mathrm{C}, \Delta \mathrm{T} \cong 400^{\circ} \mathrm{C}$

Electrolytic Etch: $10 \%$ Oxalic Acid

FIGURE 27

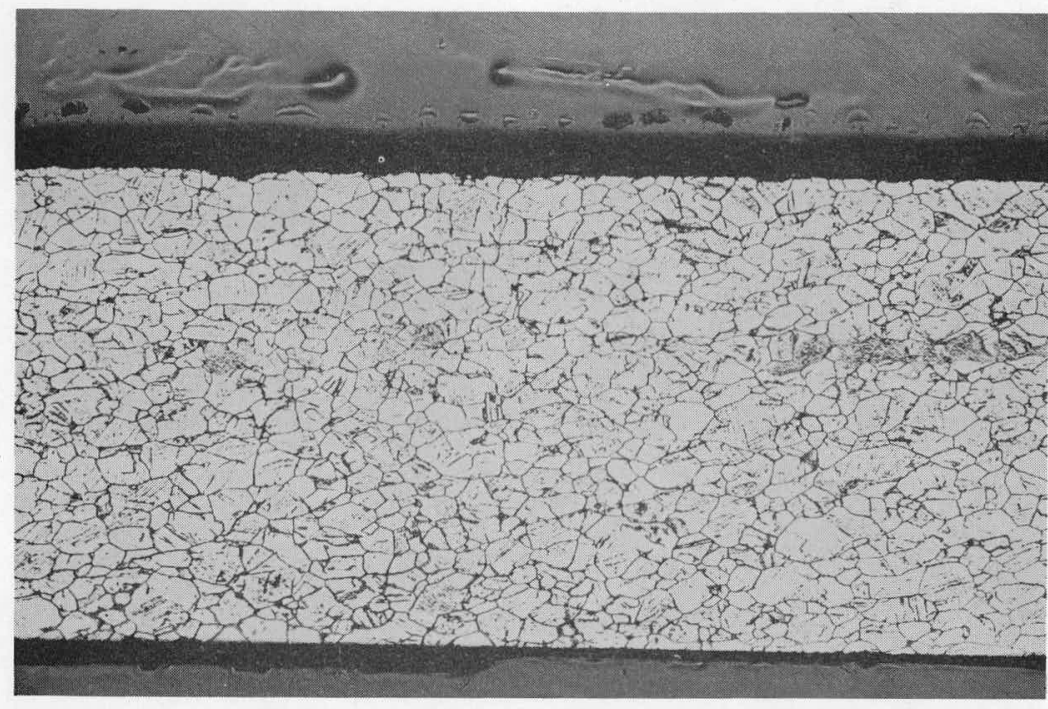

SPECIMEN 88. TEST I. A. 3.a.1. e)-1c

$\mathrm{T}=600^{\circ} \mathrm{C}, \Delta \mathrm{T} \cong 400^{\circ} \mathrm{C}$

Electrolytic Etch: 10\% Oxalic Acid

FIGURE 28 


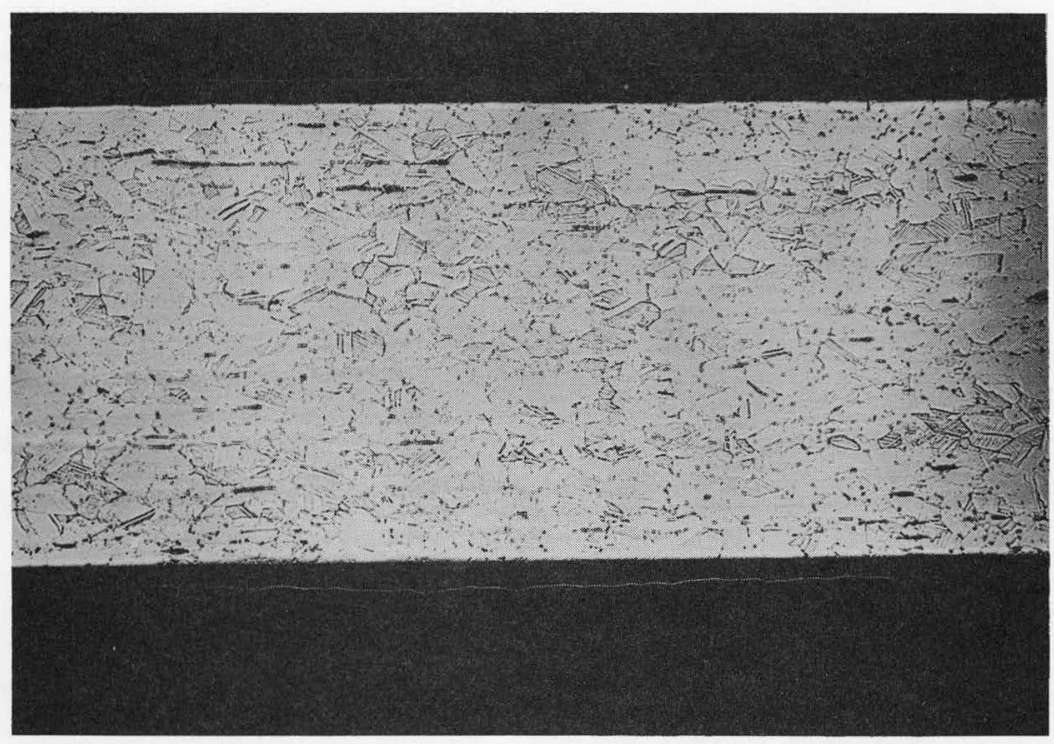

$100 x$

Neg. \#4632

SPECIMEN 83. TEST I. A. 3.a.1. f)-1a

$\mathrm{T}=400^{\circ} \mathrm{C}, \Delta \mathrm{T}=400^{\circ} \mathrm{C}$

Electrolytic Etch: 10\% Oxalic Acid

FIGURE 29 


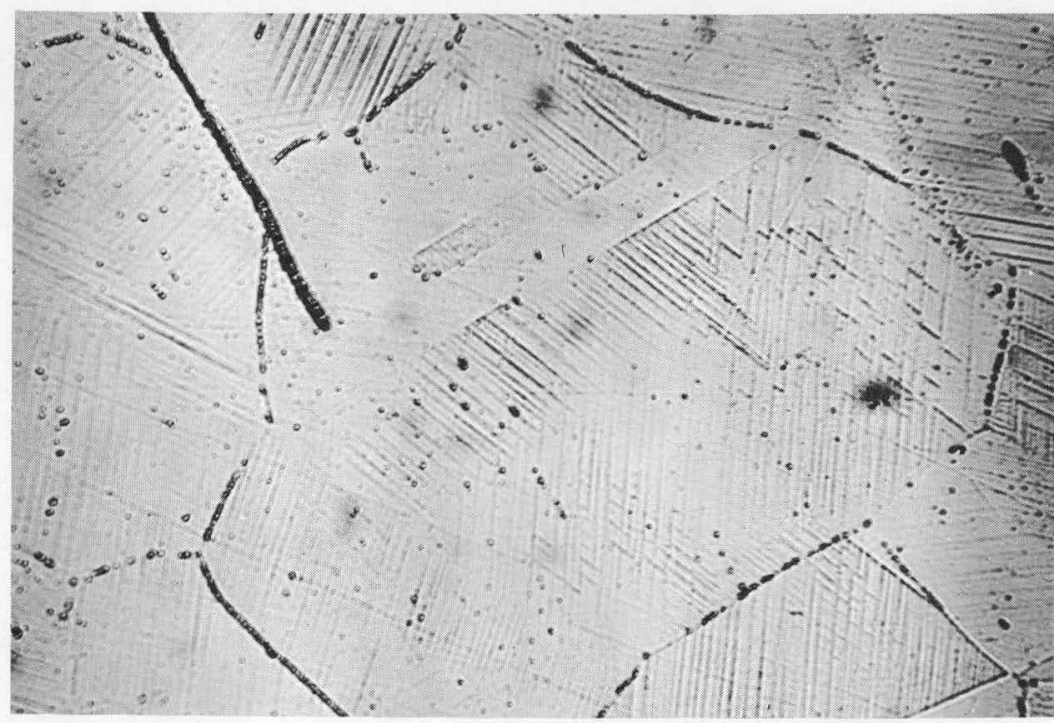

$250 \times$

Neg. \#4645

SPECIMEN 62. TEST I.A. 1.a. 1. f) -1a

$\mathrm{T}=400^{\circ} \mathrm{C}, \Delta \mathrm{T} \cong 400^{\circ} \mathrm{C}$

Electrolytic Etch: 10\% Oxalic Acid

FIGURE 30

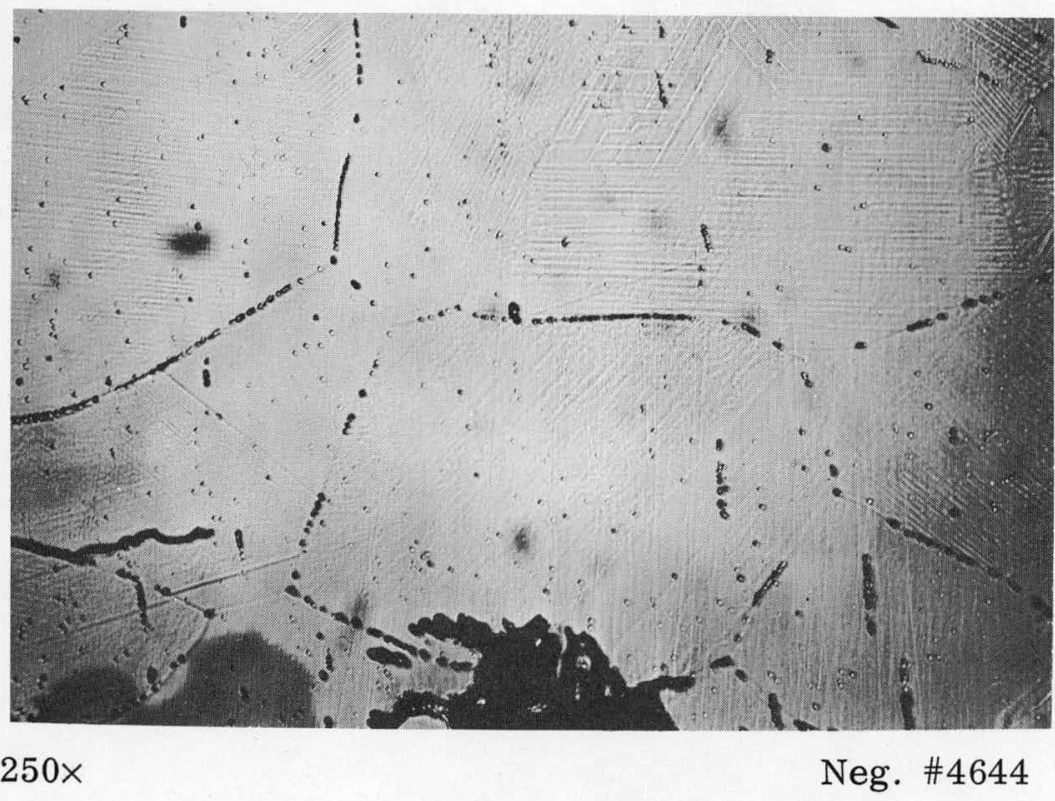

SPECIMEN 63. TEST I.A. 1.a. 1. e)-1a

$\mathrm{T}=400^{\circ} \mathrm{C}, \Delta \mathrm{T} \cong 400^{\circ} \mathrm{C}$

Electrolytic Etch: 10\% Oxalic Acid

FIGURE 31 


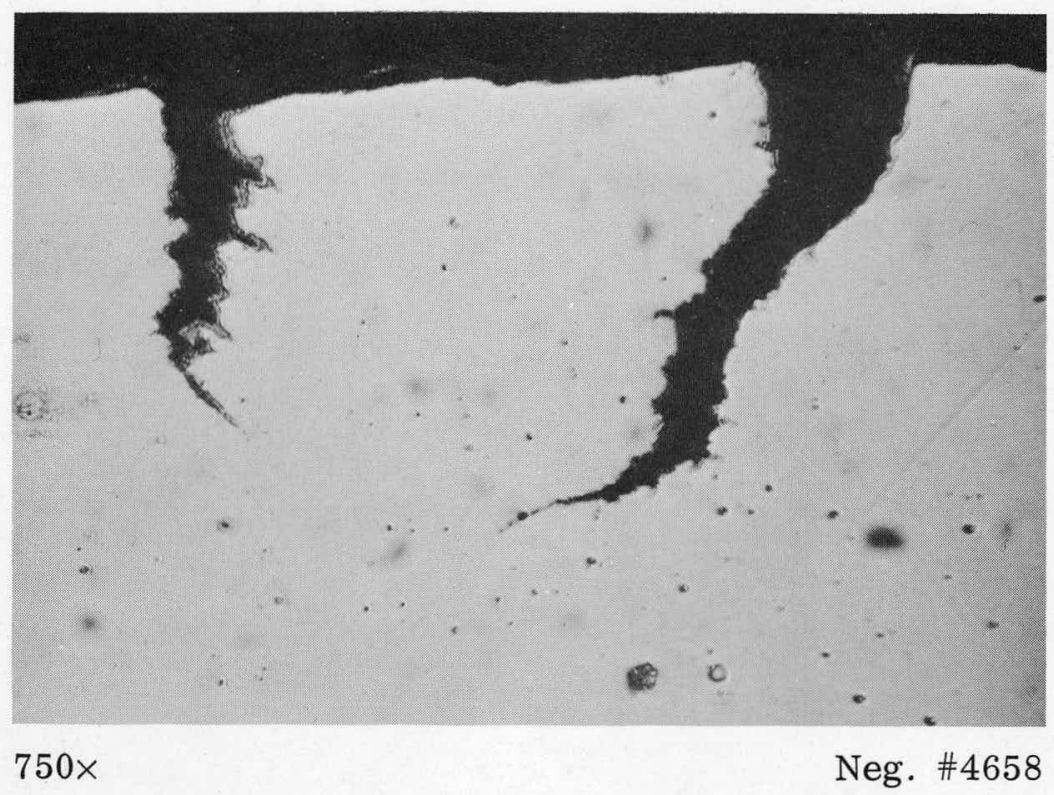

SPECIMEN 40. TEST I.A.1.a.1. a)-3c

$\mathrm{T}_{\mathrm{m}}=600^{\circ} \mathrm{C}, \Delta \mathrm{T}=500^{\circ} \mathrm{C}$ Unetched

FIGURE 32 


\section{APPENDIX \\ VARIABLES TO BE INVESTIGATED}

The investigation of the thermal-stress-fatigue variables listed below is believed necessary because: 1) data obtained should provide a thorough explanation of thermalstress-fatigue theory, and 2) such data should be applicable to actual design conditions and, hence, be useful as "handbook" data.

Structure-Sensitive Variables Structure-Insensitive Variables

1. Sensitization

2. Grain size

3. Degree of cold work
1. Strain rate

2. Hold time

3. Atmosphere

4. Specimen size

5. Temperature

6. Loading factors (e.g. , prestraining, reverse loading)

7. Stress-corrosion cracking

The testing program outlined on the following page is designed to allow investigation of all of the listed variables and to establish their interdependence. An accurate prediction of the time necessary to perform this experimental program is not possiole; however, the detail of the investigation will be a function of available time and all ciata points indicated may not be involved. A reduction in the number of data points is possible without a reduction in the number of variables to be investigated. 


\section{PROPOSED TESTING PROGRAM}

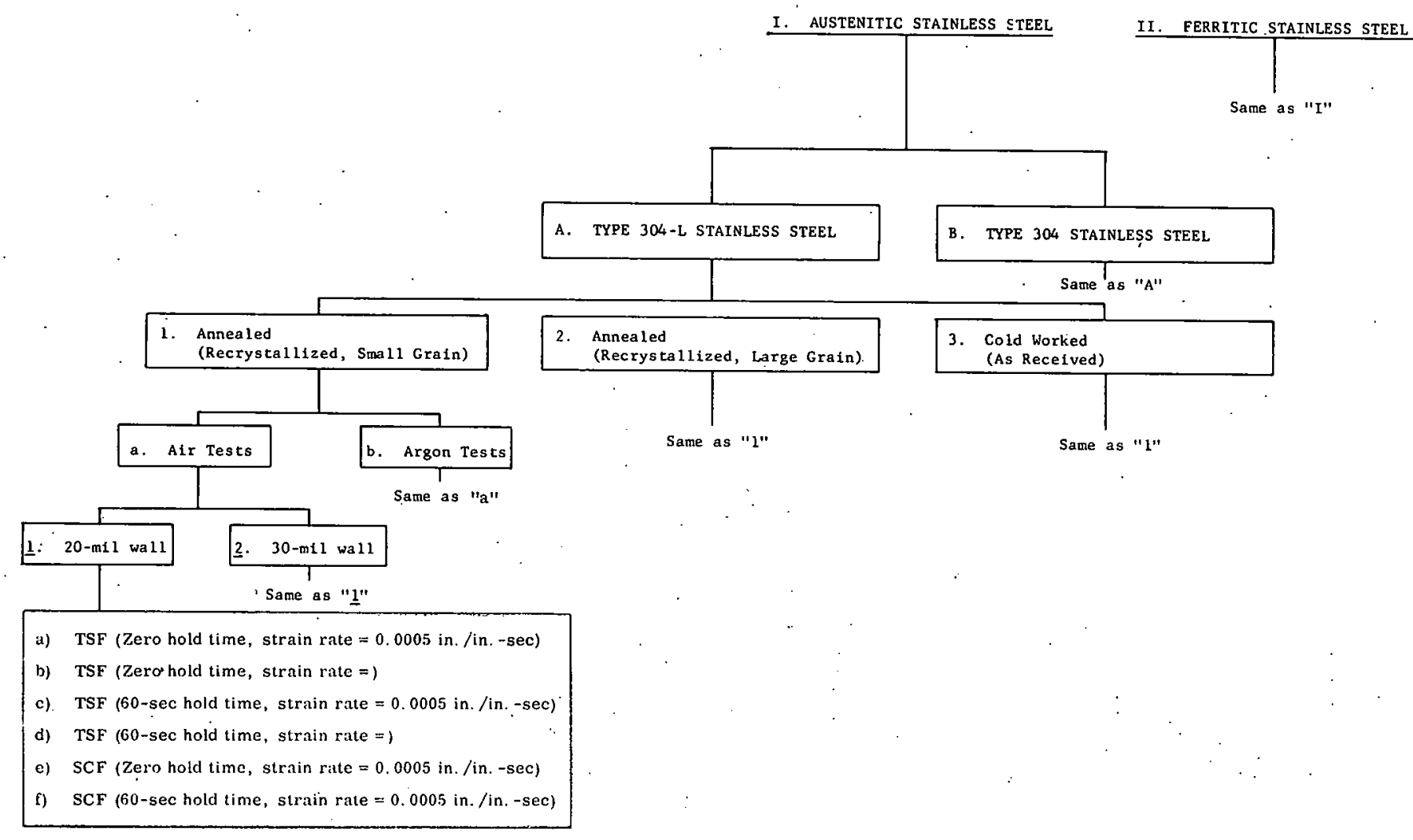

III. MARTENSITIC STAINLESS STEEL

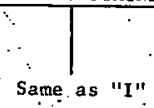




\section{DESCRIPTION OF TESTS}

(Experimental Temperatures, Temperature Changes, and Strains)

\section{Thermal-Stress Fatigue}

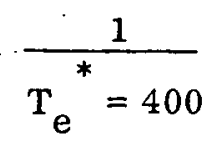

$\Delta \mathrm{T} \quad \mathrm{T}_{2}-\mathrm{T}_{1}$

a. 200

b. 300

c. 400

d. 600

* $\quad \mathrm{T}_{\mathrm{e}}=\frac{\mathrm{T}_{2}+\mathrm{T}_{1}}{2}$

$500-300$

$550-250$

$600-200$

$700-100$

$$
\frac{2}{T_{e}=500}
$$

$\Delta \mathrm{T}$

- 200

$\mathrm{T}_{2}-\mathrm{T}_{1}$

$600-400$

400

600

800
$700-300$

800-200

$900-100$

$\frac{3}{T_{e}=600}$

$\Delta \mathrm{T}$

200

400

500

600
$\mathrm{T}_{2}-\mathrm{T}_{1}$

$700-500$

$800-400$

$850-350$

900-300

Strain-Cycle Fatigue at Constant Temperature

$\begin{array}{lc} & \begin{array}{c}\text { Temperature } \\ \text { of Tests }\end{array} \\ \text { a. } & 400 \\ \text { b. } & 500 \\ \text { c. } & 600\end{array}$

$\frac{1}{\Delta T=400}$
$x$
$x$

Strain $(=\alpha \ell \Delta T)$

$\begin{array}{cc}\frac{2}{\Delta T=600} & \frac{3}{\Delta \mathrm{T}=800} \\ \mathrm{X} & \mathrm{X} \\ \mathrm{X} & \end{array}$

Notes: 1) All temperatures in ${ }^{\circ} \mathrm{C}$.

2) Test conditions will be reported as two series of numbers and letters separated by a dash. The first series is referenced to page A-2 and the

\begin{tabular}{|c|c|c|c|c|c|c|c|}
\hline \multirow[b]{2}{*}{ EXAMPLE } & & \multicolumn{4}{|c|}{ 1st series } & \multicolumn{2}{|c|}{ 2nd serie } \\
\hline & $r_{I}$ & B. & 1. & $a$. & $\underline{2}$. & c)- & $3 \mathrm{~d}$. \\
\hline & 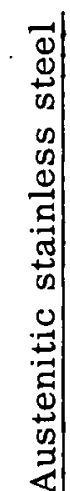 & 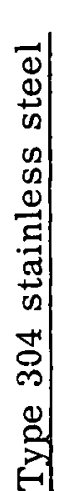 & 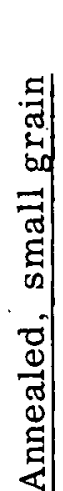 & 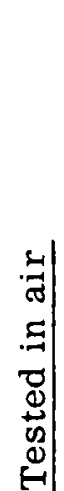 & 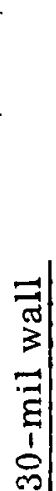 & 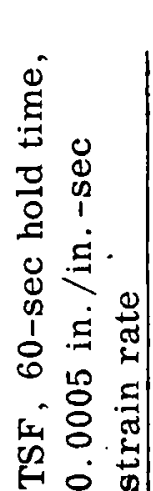 & 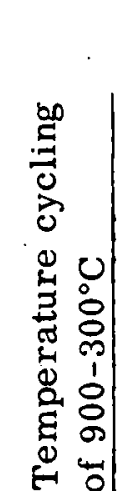 \\
\hline
\end{tabular}
second series to page A-3. 
USAEC

San Francisco Operations Office

2111 Bancroft Way

Berkeley 4, California

ATTN: W. H. Brummett, Jr.

USAEC

Division of Reactor Development

Washington 25, D。C.

ATTN: Office of Foreign Activities

Fuels \& Materials Development Branch

Nuclear Technology

1

Reports and Statistics Branch

Water Reactors Branch,

Civilian Reactors

Water Systems Project Branch

Army Reactors

Argonne National Laboratory

9700 South Cass Avenue

Argonne, Illinois

Knolls Atomic Power Laboratory

P. O. Box 1072

Schenectady, New York

Naval Research Laboratory

Washington 25, D. C.

ATTN: W. Pellini

Oak Ridge National Laboratory

P. O。Box P

Oak Ridge, Tennessee

ATTN: J.Weir

Metals and Ceramics Division

1

Professor JoDean Morrow

Department of Theoretical Applied Mechanics

University of Illinois

Urbana, Illinois 
Professor Harry Majors, Jr., Head Mechanical Engineering Department

Seattle University

Seattle, Washington

Commander, Aeronautical Systems Division

Directorate of Materials and Processes

Materials Central

Wright-Patterșon Air Force Base, Ohio

ATTN: D. Forney

Combustion Engineering, Inc.

Nuclear Division

Prospect Hill Road

Windsor, Connecticut

ATTN: W. Chernok

General Electric Company

Atomic Power Equipment Department

P. O. Box 254

2151 South First Street

San Jose, California

ATTN: T. Pashos

A. E. Carden

1

University of Alabama

Department of Engineering Mechanics

University, Alabama

ATL Files 